\title{
Franz Kossmat - Subdivision of the Variscan Mountains - a translation of the German text with supplementary notes
}

\author{
Guido Meinhold \\ Universität Göttingen, Geowissenschaftliches Zentrum Göttingen, Abteilung Sedimentologie/Umweltgeologie, \\ Goldschmidtstraße 3, 37077 Göttingen, Germany \\ Correspondence to: Guido Meinhold (guido.meinhold@geo.uni-goettingen.de)
}

Received: 5 January 2017 - Revised: 23 March 2017 - Accepted: 25 March 2017 - Published: 24 April 2017

\begin{abstract}
This work is in honour of Franz Kossmat (1871-1938) and his esteemed paper the Gliederung des varistischen Gebirgsbaues published 1927 in Abhandlungen des Sächsischen Geologischen Landesamts, Volume 1, pages 1 to 39. It constitutes the foundation of the general subdivision of the Central European Variscides into several geotectonic zones and the idea of large-scale nappe transport of individual units. In the English translation presented here an attempt is made to provide a readable text, which should still reflect Kossmat's style but would also be readable for a non-German speaking community either working in the Variscan Mountains or having specific interests in historical aspects of geosciences. Supplementary notes provide information about Kossmat's life and the content of the text. Kossmat's work is a superb example of how important geological fieldwork and mapping are for progress in geoscientific research.
\end{abstract}

\section{Introductory comments}

Franz Kossmat is a well-known scientist with a lot of achievements of paramount importance in geosciences in the first quarter of the 20th century. A brief summary may introduce the vita of Kossmat, before giving the translation of his truly groundbreaking publication, and the reader may consult the given literature (Winkler-Hermaden, 1938; Lauterbach, 1972; Seibold and Seibold, 1991; Drost et al., 2005, and references therein) for further information about Kossmat's life.

Franz Kossmat was born on 22 August 1871 in Vienna, Austria. After passing his high school exam in 1890 he began his studies at the University of Vienna where he received his degree of Doctor of Philosophy in 1894. His doctoral thesis focused on the stratigraphy of phosphorus-bearing sediments from Utatur (original title in German: Beitrag zur Stratigraphie der phosphatführenden Schichten von Utatur). He obtained his habilitation degree in 1900 at the University of Vienna. His habilitation thesis focused on the geology of the mining area at Idria (original title in German: Geologische Verhältnisse des Bergbaugebietes von Idria).
Kossmat was Privatdozent for Geology and Paleontology (1900-1909) and non-scheduled extraordinary professor at the University of Vienna (1909-1911). After his years as professor of Mineralogy and Geology at the Graz University of Technology (1911-1913), he was director of the Institute of Geology and Paleontology at Leipzig University and director of the Geological Survey of Saxony (1913-1934). During this time, Leipzig was in a leading position for geological and geophysical research not only in Germany, but also in Europe. Kossmat was 1 of the 24 founding members of the German Geophysical Society in Leipzig in 1922 (Börngen et al., 2007), and he was also a member of the society council for some time. From some time Kossmat was responsible for the seismological station in Leipzig. During his time in Leipzig, he worked not only in Saxony, but also across Europe and in the Middle East, with a major focus on the Balkans area in south-eastern Europe (Kossmat, 1924). Kossmat presented the first geological overview map of Saxony and summarized the geology in his book Übersicht der Geologie von Sachsen (Kossmat, 1916a, 1925a). In 1920, Franz Kossmat and Hans Lissner presented a map showing the first gravity measurements of central Europe (Koss- 
mat, 1921). Amongst his many publications (see WinklerHermaden, 1938), one of Kossmat's key papers during his scientific carrier is the Gliederung des varistischen Gebirgsbaues, published in 1927, which is translated into English after the introductory comments. In this paper, he established, among others, the three main zones (Rhenohercynian, Saxothuringian, and Moldanubian zones) of the Central European Variscides and the idea of large-scale nappe transport of individual units (e.g. tectonic klippen of Münchberg, Frankenberg, and Wildenfels). Geologists still use this concept today with no significant changes.

Kossmat decided to retire from his professorial position at Leipzig University in 1934 because of health problems. After a long and successful scientific carrier as geologist, mineralogist, and geophysicist, Franz Kossmat passed away on 1 December 1938 in Leipzig. Kossmat's name is still well known among geoscientists because of his impetus in combining geology and geophysics to investigate the geological history of Europe with a special focus on the Variscan mountain belt. After these introductory comments I present Franz Kossmat's Gliederung des varistischen Gebirgsbaues. ${ }^{1}$

\section{Subdivision of the Variscan Mountains}

\section{Preface}

When in the 1880s Eduard Suess ${ }^{2}$ attempted to combine the individual fragments of old mountain remains in western and central Europe into a Paleozoic mountain chain, he recognized the importance of the zones stretching from the French Massif Central through the Vosges and Black Forest to the Erzgebirge $^{3}$ and the Sudetes. From a region of this mountain chain he borrowed the name which he gave to the entire fold-belt. "Nowhere are the contours of single old mountain cores as prominent as in front of this principal line, in the Münchberg Gneiss Massif near Hof and in the Saxon Granulite Massif. It is therefore appropriate that in the coun-

\footnotetext{
${ }^{1}$ Translator's footnote (footnotes by the translator are indicated with a capital $\mathrm{T}$ to discriminate them from the original footnotes of Kossmat). Kossmat wrote his publication in German, but it is slightly different to the German used today. The translator has tried to keep Kossmat's grammatical expressions to a great extent. Some sentences are quite long and are subdivided into several commaseparated sub-clauses. The translator also recognized that Kossmat's writing style changes throughout the text. It is purely speculative, but it seems Kossmat made substantial progress in better structuring his writing and clarifying his thoughts while coming closer to the end of his publication.

${ }^{2}$ T: Eduard Suess (1831-1914), Austrian geologist; he coined, among others, the terms Gondwana-Land, Tethys, Laurentia, Variscan Mountains, Caledonian Mountains, eustasy, biosphere, lithosphere, hydrosphere, foreland, listric fault, horst, and graben (Seidl, 2009; Şengör, 2014).

${ }^{3} \mathrm{~T}$ : For convenience, throughout the text the German word Erzgebirge is preferred instead of the English term Ore Mountains.
}

try of the Varisci, the Vogtland, the name of the mountain range comprising most of the German horst regions is chosen, and the Variscan Mountains ${ }^{4}$ will be named after the Curia Variscorum (Hof in Bavaria)" (Suess, 1888, p. 131).

Since Suess published his synthesis, the systematic geological mapping by the German Geological Surveys and the Austrian Geological Survey has progressed so far that the overall picture created by Suess has been completed and deepened in many respects. On the other hand, numerous new problems of a petrographic, stratigraphic, and tectonic nature emerged during the refinement of the observations. Their solution would be extremely difficult if one had not gained new perspectives for the explanation by studying the Alpine, young mountain chains. Above all, the realization of the great importance of thrust tectonics brought in many cases the answer to petrographic and stratigraphic questions. Once again the crystalline core region of the Variscan Mountains became the focus of attention, especially as Franz Eduard Suess (Suess, 1912a, b) had recognized the major thrust faults in the Moravian eastern section of the Bohemian Massif, and soon afterwards explained the "old mountain core" of the Münchberg Gneiss Massif as a klippe ${ }^{5}$. Also within the seemingly simple anticline structure of the Erzgebirge and the Saxon Granulite Massif one could more and more recognize the effects of major tangential movements in the crystalline basement (Kossmat, 1916b; Scheumann, 1925).

The exploration of the outer fold belts of the large mountain range, especially in the Rheinisches Schiefergebirge ${ }^{6}$ and the Harz Mountains, is so far advanced, after overcoming great difficulties, which the structure of the Paleozoic strata posed, that the attempt is worthwhile to develop an overall picture of the Variscan Mountains according to our present knowledge. Since the Saxon Mountains represent one of the theoretically most important sections of the Variscan arc, I consider it justified to open the first issue of the Abhandlungen des Sächsischen Geologischen Landesamts with such a summary, in order to characterize the location of Saxony in the geological framework of central Europe.

\footnotetext{
${ }^{4}$ The newer spelling is usually "varistisch", but some authors prefer the spelling "variszisch" or "variskisch".

${ }^{5} \mathrm{~T}$ : A klippe is an erosional remnant of a formerly continuous nappe. The reader is referred to Tollmann (1987) for further details.

${ }^{6} \mathrm{~T}$ : For convenience, throughout the text the German word Rheinisches Schiefergebirge is preferred to the English term Rhenish Slate Mountains. Karl von Raumer (1783-1865), a German geologist and educator, coined the term Rheinisches Schiefergebirge, defined its borders, and showed it for the first time as a geological unit. Von Raumer $(1815$, p. 10) wrote "Schiefer herrscht vor allem andern Gestein in unserm Gebirge, welches ich deshalb nach ihm nenne" [sic], which can be translated into English as follows: "Slate dominates above all other rocks in our mountains, which I therefore name after it".
} 


\section{The Variscan phases of movement}

The orogenetic processes leading to the construction of the Variscan Mountains extended to an extraordinarily long period, from the end of the Devonian period to the younger Dyas $^{7}$. Stille (1925) has divided the course of these movements into phases which he characterizes in terms of discordances in the layer sequence as follows:

Breton phase between Upper Devonian and Lower Carboniferous,

Sudetic phase between Lower Carboniferous and lower Upper Carboniferous (Waldenburger Stage),

Asturian phase between Saarbrücker and Ottweiler stages of the uppermost Upper Carboniferous,

Saalian phase between lower and upper Rotliegend,

Palatine phase between upper Dyas and Buntsandstein (more correctly between upper Rotliegend and Zechstein).

It should be added that in Saxony there is a pronounced orogenetic phase between the lower and middle Upper Carboniferous, that is, between Waldenburger and Saarbrücker stages. In the sense of the above outline, I call it the "erzgebirgische Phase", which is to be inserted between the Sudetic and Asturian phases. The main phases of folding of the Variscan Mountains occurred in the first four phases, with the Sudetic and Asturian phases being dominant, although the Breton discordance is very prominent in large areas, especially in the more central parts of the mountains. The movements of the Saalian and the Palatinate phases already show the decay of the main mountain formation process. Stille's ${ }^{8}$ categorization into phases is undoubtedly very useful for a clear description of the processes and for the temporal comparison of the individual mountain zones, if one keeps in mind that it let appear the rhythm of the orogenetic processes too strictly graded, since it naturally only highlights their culminating points.

${ }^{7} \mathrm{~T}$ : The term Dyas was introduced by Jules Marcou in 1859 and was used in Germany for the Permian (Geinitz, 1861). The older and better known term Permian was coined by Sir Roderick Impey Murchison. The usage of Dyas instead of the older and better term Permian led to much debate (Murchison, 1862).

${ }^{8}$ T: Hans Stille (1876-1966), German geologist.
The subdivision of the Variscan mountain zones

\section{A. The western part of the fold belt between the Maas and the Elbe}

\section{The marginal folds (Westphalian Zone)}

In the same way as the young mountain chains of Europe are separated from the frontal parts of the continent by a filled fore-deep (Alps and Carpathian Foreland) with a thick succession of eroded material, the Variscan mountain range is accompanied by a long depression on its northern side. This formed a sedimentation trough in which non-coal-bearing sandstones were deposited concordant above Lower Carboniferous, and then the productive hard coal beds were deposited with a thickness of several thousand metres. This concordant deposition also took place at times when the older main phases of folding occurred in the interior of the mountain range. First the Asturian movements also affected the outer zone.

In the northern French-southern Belgian coal district, where the spread of the Variscan Mountains was hindered by the old Brabant Massif (Cambrian and Silurian with a discordant overlying Middle Devonian), the coal belt was forced into a strongly compressed depression, over which the Ardennes advanced along flat thrust faults. Such conditions dominate the border area up to the Aachen coal mine. Further east, at the same time as the submerged Brabant Massif, a freer development of the folding takes place. The extent of the thrusting is reduced, while at the same time the coal zones continue to move northwards in the Ruhr area. In the subsurface of the Lower Rhine Bay, a swivelling of the margin of the mountain range took place, which Eduard Suess designated as "Sigmoide". He compared it with the swivelling which, on the boundary of the Eastern and Western Alps, affects the course of the tectonic zones far into the mountain. Numerous cross-cutting faults are connected with this phenomenon.

The sharp tectonic demarcation of the coal belt against the southern neighbouring mountain zones is no longer present in the Ruhr area. On the contrary, it is observed that individual anticlines, such as the Velbert Anticline, enter the Carboniferous belt in a scenery-like manner, and generally submerge towards the east (Paeckelmann, 1926).

In the northern part of the Ruhr, the folds become weak and finally appear flattened on the subsurface of the Dutch plain. In this way, the coal field is likely to extend to the North Sea, and finally reappears in the low-lying Carboniferous regions of north-eastern England. One could speak of a North German Great Trough in this part of the former Variscan foreland. 


\section{The Greywacke zones of the Variscan Mountains (Rhenohercynian zones) ${ }^{9}$}

\section{A. The Sauerland-Oberharz Zone (Ardennes Zone west of the Rhine)}

As already mentioned, the Ardennes Zone west of the Rhine borders with a large thrust fault the southern margin of the Belgian coal belt. It was also here, for the first time in the Variscan Mountains, that denudation remnants of the thrustup mountain parts were discovered in the form of klippes above beds of the coal-bearing syncline. A discussion of the details of these phenomena is not planned in this work.

The Silurian and Devonian beds pushed to the north sink southwards in individual folds, forming the Carboniferous Dinant Syncline. The older strata rise up again on the opposite side, so that in the region of Rocroi and the Hohes Venn ${ }^{10}$, the Cambrian group of rocks appears below the transgressional overlying Lower Devonian. A line, which follows the axis of this anticline, intersects at an acute angle the strike of the northern margin of the mountain, which here has an east-north-easterly direction, while the mentioned anticline strikes north-east. Therefore, the two tectonic elements converge in the direction of the Rhine. This may be related to the submergence of the Brabant Massif and the resulting advancement of the Variscan arc. In the Hohes Venn, the convergence has advanced so far that the tightly compressed Devonian and Carboniferous beds of the southern part of Marginal Zone I are exposed in the window of Theux, underneath the upward-thrust Lower Devonian and Cambrian of the Ardennes (Anonymous, 1920).

Further inward, the Middle Devonian Eifel Syncline belonging to the south-eastern wing of the large Ardenne Anticline also shows the arrangement oblique to the general eastnorth-eastern strike of the mountain.

In the eastern part of the Rhine region, as the most important building element, the Lower Devonian Siegen Syncline east of the Eifel Syncline region comes to the fore. It also has a tendency to approach in the north-east the outer zone of the mountain range. On the northern margin, in the Sauerland, there is often overturned folding, but opinions are still divided. It does not appear to be the case of thrust faults of first order, but rather of overturned folding, and partly advancing of the higher rock packages. There are, however, phenomena which are part of the continuation of the southern Belgian major thrust fault zone.

The occurrence of various special anticlines, from which the northernmost dies out in the marginal Carboniferous region, has already been mentioned (Paeckelmann, 1926).

\footnotetext{
${ }^{9}$ The author suggests the names "Rhenohercynian Zone" for II and "Saxothuringian Zone" for III (Chapter III).

${ }^{10} \mathrm{~T}$ : For convenience, throughout the text the German word Hohes Venn is preferred instead of the English term "High Fens".
}

The Lower Devonian of the Siegen Anticline descends towards the north-east like the keel of a capsized ship, so that the axis is then formed by the East Sauerland Middle Devonian. Finally, it runs narrowly into the north-eastern tip of the Rheinisches Schiefergebirge. In the north and south-east, the limbs of the main anticline are made up of Upper Devonian and $\mathrm{Culm}^{11}$ : in the north, these strata form the margin of the Ruhr Carboniferous, and in the south-east they represent the youngest horizons of the Lahn-Dill Syncline, divided into numerous thrust stacks and folds. To the south of the latter rises a new, widely running tectonic element, namely the Hunsrück-Taunus Zone, whose Lower Devonian and partly even older rocks form the southern heights of the Rheinisches Schiefergebirge.

From the eastern margin of the Rheinisches Schiefergebirge and the northern Kellerwald, which submerge beneath the post-Variscan younger rocks, the tectonic arrangement leads us into the narrow, Culm greywacke ridges of Allendorf on the Werra, further into the Upper Harz (north-western Harz) and beyond to the Culm area of Magdeburg. As in the tectonically disturbed areas of the Lahn-Dill Syncline as well as the Kellerwald, we have an east-north-east-striking system of folds and thrust stacks of the Culm and the Devonian. In general, the Culm prevails, while the underlying layer is exposed mostly in the form of more or less narrow thrust stacks of the Upper and Middle Devonian. The most important zone of this type is the so-called Upper Harz Greenstone Belt between Osterode and Altenau. Only in the area south of Goslar is, as wide, north-west-folded anticline, the Lower Devonian of the Kahleberg still exposed. This uplifting seems to be in the same direction as the large Devonian anticline in the northern Kellerwald. In the south-west, the Kahleberg Anticline is bordered by the west-north-weststriking fault of Bockswiese-Schulenberg, against the Culm of Clausthal, which is traversed here by numerous veins.

\section{The Iberg Klippe}

Strangely isolated, a fossil-rich cliff of reef limestone of the lower Upper Devonian, which is limited all round by faults, occurs in the Culm area of the north-western Harz at the Iberg near Grund. The tectonic interpretation of this peculiar occurrence encounters difficulties. At first we might think of the fact that here, in the south-western extension of the strike of the cut-off Kahleberg Anticline, there is a horst, which has again brought a piece of Devonian in the middle of the lowered part of the Culm. It would be difficult to understand, however, that the higher Upper Devonian is not visible, and that the Iberg Limestone is a facies which is not found elsewhere in the north-western Harz. For this reason, Welter (1910) has explained the Iberg Limestone Block not as a horst, but as the last denudation residue of a pushed-up

\footnotetext{
${ }^{11} \mathrm{~T}$ : Culm (also known as Kulm) is often used as a synonym for synorogenic flysch-type deposits of Carboniferous age.
} 
mountain mass, that is, in the manner of the Swiss klippes. The question has not been followed. At the present time, however, it would have to be investigated again, because it was found that the intensity of the tangential movements in the Harz was much greater than had previously been thought. The overturned folds and thrust stacks of the Upper Harz are not the greatest dimension of the tectonic movements. On the contrary, we are dealing with large shearing processes in the eastern parts of the mountain range, which go so far that the Lower Harz (middle and eastern Harz) was transported as thrust nappe over the eastern folds and thrust stacks of the Upper Harz. The latter are exposed in the middle parts of the mountain range near Elbingerode and Tanne by denudation as windows. In the meantime, I would like to leave open the question as to whether the Iberg Klippe was connected with these eastern occurrences or whether it can have its origin in the thrust stacks of the Upper Harz Greenstone belt of Osterode-Altenau. In the latter case, however, the Iberg Limestone is not known, but the Stringocephalus Limestone of the upper Middle Devonian is, which is already related to it in its facies, and is often associated with it. In the window of Elbingerode the Iberg Limestone is even found in such a relation. The idea would not be easy to point out that the squeezed parts of this rock were pushed forward into the north-western Harz and that they are preserved here as Iberg Klippe. In any case, further investigation of this problem is needed.

\section{B. The Lower Harz Nappe}

The south-easterly dipping folds and thrust stacks of the Devonian and Culm in the north-western Harz are bounded to the south-east by the ridge of the Acker-Bruchberg, whose stratigraphy has not yet been fully clarified despite many investigations. Its quartzites are reminiscent of many parts of the Silurian and the Rhenish Lower Devonian. Since typical lepidophyte remnants of the Culm have been found in similar rocks near Ilsenburg in the north-eastern extension of the Acker-Bruchberg, one must reckon with the presence of this group. Generally, the Acker-Bruchberg seems to be a complex rock zone due to tectonic intermixing. Devonian is certainly represented on the south-eastern side, where northwesterly dipping Lower Devonian greywackes and Middle Devonian slates occur as a long succession. They lie in the seeming hanging wall of the wide Culm zone of the Sieber valley and are separated by these from the Devonian and Silurian of the area of Andreasberg. To the south of the latter strip one enters the much-discussed Tanne Greywacke Zone, which was once considered by Beyrich and Loßen to be the main anticline of the Harz, but which, on account of its plant remnants, is younger than both flanks.

In the case of the Lower Harz there are, therefore, very remarkable tectonostratigraphic conditions, which differ markedly from the relatively easy-to-see thrust stacks structure of the north-western Harz, and have always presented great difficulties for the interpretation. The key to solving this problem lies, in my opinion, in the Elbingerode area (Kossmat, 1927a), of which the stratigraphy is particularly well understood based on the documentations by Max Koch. The region of Elbingerode is encircled all around by pushed-up Middle and Lower Devonian beds (Fig. 1). It consists of a few fairly regular anticline cores of Middle Devonian volcanoclastics ${ }^{12}$, the flanks of which are built of ironbearing Stringocephalus Limestone, of Upper Devonian and of Culm, and thus dip beneath the peripheral thrust zone. One has the typical exposure of a window. The thrusting must have come from the south over the region, with the lydite ${ }^{13}$ horizon, under- and over-lain by alum slate, being abraded to a rather large extent, but being accumulated on the northern side of the window. The thrust fault has subsequently been bent by continuous folding. The Elbingerode Complex underneath itself was thus exposed where the arching of the mountain range occurred.

This later fold, which partly led to the overturning of the northern margin of the window, undoubtedly delayed the recognition of the tectonic nature of the area. But, after receiving my work (Kossmat, 1927a), Erdmannsdörfer sent me a hand-drawn sketch from 1919, which had shown the phenomena in the eastern part of the Elbingerode area by anticlinal bending of a uniform, north-directed thrust fault, but of a more local character.

In the same way as Elbingerode, I explain the Tanne Greywacke Zone, of which, in the year 1870, Ernst Beyrich wrote in the explanatory notes to sheet Zorge: "The Tanne Greywacke, with the anticlinal bending of the layers, which has been proved several times, forms the footwall of the Wieder slates (i.e. the Middle to Upper Devonian) surrounding it, and must accordingly be regarded as the oldest layers which appear in the Harz at all." This seemingly so accurate conclusion proved to be wrong. The Tanne Greywacke Complex, in its facies, strikingly corresponds to the Culm, is underlain by platy clay slates and a lower lydite horizon, and is, according to its Cyclostigma flora (with Knorria) much younger than the strata considered earlier as its stratigraphic section in the hanging wall ${ }^{14}$. I consider the stratification

\footnotetext{
${ }^{12} \mathrm{~T}$ : The original term Schalstein was translated as volcanoclastics, and refers here to diabase breccias and diabase tuffs, which show a foliation.

${ }^{13} \mathrm{~T}$ : A variety of radiolarian-bearing black chert.

${ }^{14}$ The exact stratigraphic age of the Tanne Greywacke requires further clarification. The statement by Bode (1923), quoted by me in the last paper (Kossmat, 1927a), that Nathorst suggested a Carboniferous age of Tanne Greywacke, is to put right here that Nathorst compared the few flora remnants with Upper Devonian occurrences. Gothan, too, in a publication by Schriel, which has been kindly made available to me in the correction proof, puts the Cyclostigmabearing beds in the horizon of the Upper Devonian of Bear Island. By the way, it is generally stated that the young Devonian flora already corresponds practically to the Culm type (see e.g. Wedekind's
} 


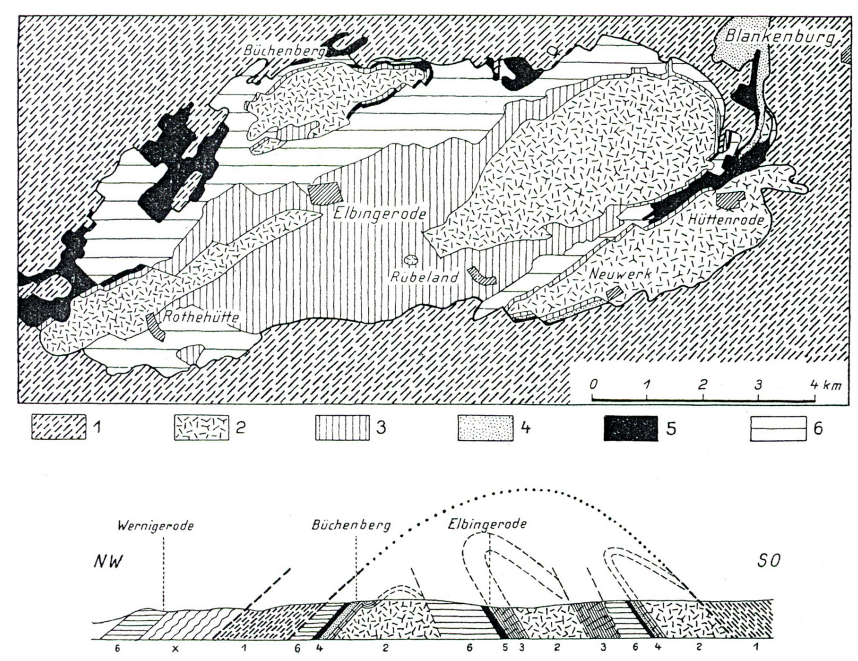

Figure 1. Sketch map and profile of the window of Elbingerode in the Harz. Sketch map based on Plate 2 of the geological guidebook of the Harz Mountains by Dahlgrün et al. (1925). On the eastern side of the window are a few small modifications. Profile according to Koch (1897). The zone of Wernigerode would be presented differently according to recent knowledge. Lower Harz Nappe: 1: Lower Devonian and Wissenbacher slate. Window of the Upper Harz Series: 2: anticlines of Middle Devonian volcanoclastics, in the eastern Elbingerode Anticline with intercalations of Tentaculite slates. 3: iron-bearing Stringocephalus Limestone of the upper Middle Devonian with Iberg Limestone of the lower Upper Devonian. 4: Buntschiefer and Clymenia Limestone of the Upper Devonian. 5: Culm lydite. 6: Culm clay slates and greywacke. The peripheral outcrop of the thrust fault, which is assumed to be uniform here, is represented by a thick line. x: "Silurian" at Wernigerode (only in the profile). In the original publication, Kossmat (1927b) refers to these figures as individual figures, i.e. referring to Figs. 1 and 2, although they are shown together. For simplification, in the present translation, they refer to a single figure only. Source: Library of the University of Göttingen.

conditions of this zone, expressed by Beyrich and Lossen, also expressed on the Harz map 1:100000 in the same way as those of Elbingerode, and also consider the Tanne succes-

description of the Devonian in Salomon's Principles of Geology, Volume II, p. 201). I should, therefore, believe that other plant specimens, possibly in the higher greywackes, are still to be expected till the age diagnosis can be determined. It is noticeable to me that the sequence of lydite above clay slate to greywackes and conglomerates is exactly the same as in the clear Culm, which in the Sieber valley in the Harz is only separated by a narrow Devonian ridge from the Tanne succession. Moreover, if the latter was assigned to the upper Devonian strata and to the boundary horizon with the Lower Carboniferous, it would also be necessary to reject Bode's statement of the presence of Carboniferous animal remains (Cyathaxonia cornu, among others). For the above tectonic considerations, the decision of these questions does not play an important role. Only the Culm facies in the Tanne succession would start earlier than in the north-western Harz, if the layers in question were still the uppermost Devonian. sion as a window in the middle of the Lower Harz (Kossmat, 1927a). The idea that in most of the profiles on the northern side of the Tanne Zone the Devonian layers, which had originally been considered as being pushed up, dip beneath the mentioned greywackes, does not alter the nature of the phenomenon. It is simply connected with the fact that the folding processes, which have continued after the thrusting, still operated as in the further north-westward region of Elbingerode. There too, there is an overturning of the anticlinal structures of the window. In the thrust belt regions of the Alps, such and often much larger deformations of the thrust planes are a well-known phenomenon.

The pushed up Lower Harz Nappe is intricately imbricated and shows in an area, designated by Dahlgrün et al. (1925) as Silurian axis, an almost continues series of fossil-bearing exposures of Silurian age. These range from Lauterberg over Hasselfelde and Harzgerode to the eastern part of the northern margin of the Harz. Flat thrust faults are observed here.

With the already mentioned Acker-Bruchberg ridge the north-western margin of the Lower Harz nappe system is reached. The former owes its preservation to an introversion into the Culm of the Upper Harz, which is exposed due to denudation on the one side in the Söse area and on the other side in the Sieber valley. The distance of thrust displacement of the Lower Harz is estimated to be more than $25 \mathrm{~km}$ on the basis of the above interpretation of the situation of Elbingerode and Tanne.

\section{C. The Stieger Nappe}

There is still a layer of beds on top of the Lower Harz Nappe, which I would like to call Stieger Nappe (Kossmat, 1927a). The folded Silurian and Devonian is overlain in the Southern Harz Syncline with discordance by a peculiarly mixed group of beds, which, according to descriptions of Dahlgrün et al. (1925), is rich in diabase in the lower parts of the northern margin, and is also composed of a mixed group of ruffled clay slates, greywacke and quartzite lenses, Wetzschiefer ${ }^{15}$ and lydites, and individual conglomerates. The hanging wall is formed by Culm lydites, clay slates and greywackes. Rotliegend lies discordant above.

Dahlgrün et al. (1925) and Schriel (1925) suggest that the Stieger Complex is lowermost Lower Carboniferous, overlying transgressively Devonian and Silurian. I cannot share this opinion because of the present circumstances, but consider the Stieger Series as a variegated complex, which may enclose different horizons of Devonian and Carboniferous

\footnotetext{
${ }^{15} \mathrm{~T}$ : Abraham Gottlob Werner (1749-1817), a German geologist and originator of the theory of Neptunism, coined the term Wetzschiefer (Werner, 1787, p. 11; Ludwig, 1804, p. 112, 113) that is translated into English as whet slate (Jameson, 1804, p. 331-333). Wetzschiefer describes a variety of slate, which is quartz-rich and commonly greenish-grey in color, and when cut and polished, it is used for sharpening knives and other cutting instruments.
} 
rocks, perhaps even Silurian, and is separated from the underlying bed by a thrust fault. That this is not a transgression deposit is also evident from the fact that the maps to the west of Stiege between the mentioned complex and the underlying bed again contain lots of Culm lydites (Dahlgrün et al., 1925, p. 146; and the Harz map by Lossen).

In the upper part of the Stieger Complex, Schriel (1925) has already observed shearing, on which the hanging Culm greywacke has moved forward in a flat manner. The outcrop of these shear planes shows a conspicuous parallelism with the outer margin of the entire Stieger Complex on the mentioned map section of Stiege, which, in my opinion, is also an indirect proof of the tectonic nature of this boundary. To the Stieger Nappe, I also count the metamorphic series of the south-eastern margin of the Harz and the Selke Syncline, which appears south of Ballenstedt under the discordant Rotliegend and offers the same stratigraphic profile as at Stiege.

One gets the impression that the Stieger Nappe overall is to be regarded as the south-eastern hanging wall of the Lower Harz Series, which was pushed a considerable distance along detachment surfaces, picking up together various rock layers over the folded main part of the Lower Harz Zone.

The preceding tectonic interpretation of the stratigraphic conditions was developed by the author in the winter of $1926 / 27$ on the basis of the literature and maps. When it was possible for him to examine the gained opinion on the spot, it became clear that the basic information of the new interpretation were not only found in the area of Elbingerode, but also in that of Tanne and Stiege. For Elbingerode, there could be little doubt in this respect after the observations by Koch and Erdmannsdörfer. But also in the much-discussed zone of Tanne, it became clear that the relations of the Tanne Greywacke and the Plattenschiefer were indeed to be described as occurring under the Lower Harz Devonian Series, even where their northern margin is overfolded on it. Where the Devonian slate and diabase run out in narrow tips, for example, north of Voigtsfelde and north of Tanne, they emerge. The contacts with the Tanne Greywacke are tectonic, and the deepest horizons of the latter, namely, the Plattenschiefer, form the core of the ridge, and have at Tanne in remarkable extent the anticlinal-shaped stratification emphasized by Beyrich.

Very interesting are the cliffs near Bad Lauterberg. The locality of graptolite slates of the Silurian occurs under a group of diabase, ruffled slates and Culm lydites belonging to the Stieger Nappe, but separated from it by erosion. Below, the Tanne greywackes dip in a south-westerly direction.

The Devonian limestone cliff of the Rothäuser valley north-west of Bad Lauterberg, which is distinguished by its Hercynian fauna north-west of Bad Lauterberg, was investigated by Bode (1923), who found through his excavations that the contact with the Tanne Greywacke is tectonic.

As far as the "Silurian" area of Wernigerode is concerned, the author has the impression, based on his crossing the area, that lydites, cherty limestones, and Plattenschiefer of the Culm are exposed here, and that this zone, together with the Culm greywackes of the Schlossberg and Tiergarten, tectonically belongs to the Upper Harz Series. It is separated from the Elbingerode window by an area a few kilometres wide of Middle and Lower Devonian of the Lower Harz Nappe. The profile of Max Koch (see Fig. 1) requires correction here. Since the Cardiola interrupta, on the basis of which the assignment of the Wernigerode beds to the Silurian was made, comes from a mining stockpile, the whole question seems to require a re-examination.

\section{Equivalents of the Harz nappes in the Kellerwald and Lahn-Dill region}

If the concept of the Harz given above is correct, these phenomena cannot be isolated, but must show up somehow, in view of the great extent of the movements, in the continuation of the same Variscan mountain zones.

There is, of course, little to be said about the relations to the east. Here it is only known that a pale quartzite appears near Gommern to the east of the zone of the Culm greywackes of the Flechtingen ridge (continuation of the Upper Harz Zone). It corresponds in its nature and in its plant occurrences to the quartzites, which have yielded Culm Knorria at Ilsenburg and belong to the Acker-Bruchberg Zone. Consequently, a formation of the Culm occurs, which is alien to the Upper Harz, but is known in the frontal zone of the Lower Harz Nappe.

If we go from the Harz to the south-west, we find on the left side of the Werra at Sooden-Allendorf, in the middle of the Zechstein-Triassic area, the narrow greywacke horst, whose rocks Beyrich compared with the Tanne Greywacke (Moesta and Beyrich, 1886). Plant remains such as Archaeocalamites are quoted. On the south-eastern side of this zone, slate and diabase are found in the apparent hanging wall, which are comparable to the Devonian complex of the Lower Harz, i.e. the "Wieder beds" of Lossen. The entire profile is reminiscent of that of the southern border of the Tanne Greywacke Zone in the Lower Harz.

Significantly more important are the occurrences in the Kellerwald. The rock formation, which is found in the south of the normal Devonian-Culm profiles of the northern Kellerwald, appears to me to be a picture of a folded nappe outlier of rocks of the Lower Harz. On its northern side, the map of Denckmann (1901, Plate 2) shows a whole number of small quartzite cliffs, enclosed by Upper Devonian and other layers. In the south, the proven Silurian zone is bounded by a Culm region, whose lydites, according to Denckmann's conception, are transgressive above Silurian, as they dip away from it. I believe that such a stratigraphic discordance might be different. Although the Culm lydites, because of the radiolarians occurring in them, do not have to be deep-sea formations, they do not have the character of the basal strata 
of a transgressive complex with a strong discordance. After an orogenic movement, which was so radical that, in a geologically short time (between the upper Clymenia Limestone and the Lower Carboniferous), the folds could be removed except for the Silurian, one would have to expect different basal layers of an overlying sequence of strata. It is much more probable, as in the case of the Lower Harz, that the apparently horst-like Silurian-Devonian ridge is only the rest of a group of strata pushed onto the Culm. Their preservation would be due to the fact that they were subsequently tectonically trapped, their original footwall, namely, the Culm, which they had overthrust, being folded, or stacked.

Strangely similar conditions are found in the border area between Lahn and Dill synclines. The Lahn Syncline in the south, the Dill Syncline in the north, have strata of the Devonian and Culm, which strongly resemble the area of Elbingerode and the Upper Harz, and with them undoubtedly must be assigned to the Sauerland depositional region in the broad sense. Volcanoclastics, iron ore-bearing Stringocephalus Limestone and other strata are linked in all these areas to a related facies group.

Between these two strongly tectonized synclines there is a facies which is particularly connected with the region on both sides of the Hörre.

Ahlburg (Kegel, 1922) referred to it as the northern marginal facies of the Lahn Syncline and designated its area as "horst area of the Hörre". Klippen quartzite [Silurian?, possibly also Lower Devonian], Koblenz beds, Middle Devonian slate with the famous deposits of the "Hercynian" limestones of Greifenstein, Ballersbach, Günterode and with occurrences of Pentamerus Quartzites characterize this "Horst area". It is remarkable tectonically that the strip of the abovementioned Hercynian limestones of Greifenstein, Ballersbach, and Günterode forms precisely the northern margin of the Hörre Zone, which has been pushed up on Culm strata of the Dill Syncline. In the Marburg area, that is, in the eastern extension in strike direction of the "Horst Zone", graptolitebearing Silurian and Hercynian Lower Devonian have been identified. The occurrence clearly points to the moderately distant area of the southern Kellerwald.

The Hörre Greywacke and the Plattenschiefer associated with them caused great difficulties. After having been assigned to the Silurian for a long time, Ahlburg has placed those in the Upper Devonian ${ }^{16}$. The flora of the Plattenschiefer did not seem to contradict it. Kegel has recently come to the following conclusion: "It is indeed clear that most of the feldspar-rich greywackes, which have hitherto been designated as Hörre Greywacke, cannot be distinguished from the Culm greywacke in the hand specimen as well as in the composition of the rock sequence, as long as certain quartzitic sandstones and greywacke sandstones are disregarded. This part of the Hörre Greywacke, which the

\footnotetext{
${ }^{16} \mathrm{We}$ are reminded of the changing views about the Tanne Greywacke.
}

new recordings have taught, is now connected with platy slates (a part of the Schiffelborn beds) in such a way that as a normal succession the series of lydite, clay slate, and greywackes catch someone's eye in numerous places. It was found that these rocks are located in smaller and larger synclines and fragments of a different kind of core of the Hörre rocks. Where, as for instance south of the Mühlberg near Katzenfurt, the axis of such a Culm syncline comes up, the lydites have been preserved in larger thickness. On the flanks of the synclines they are often no longer detectable, whether they were originally lacking or were falling victim to tectonic movements" (Kegel, 1925, p. 293, 294).

The presumption that it was Culm was confirmed by the fact that occasional Lepidodendra were discovered by the Geological Institute at the University of Giessen in the Hörre Greywacke, which W. Gothan recognized as undoubtedly Culmian. Also the previously identified flora of the Plattenschiefer of Sinn is to be assigned to the Culmian; it was assigned in the past to the Upper Devonian only on account of its geological reasons.

At the same time, a clarification has also been made on the Giessen Greywacke, which had previously been assigned to the Upper Carboniferous. They are, like the Hörre Greywacke, accompanied at the base by lydite and also belong to the Culm. In the region of Giessen, that is, in the middle part of the Giessen Greywacke Syncline, Silurian and Pentamerus-bearing Middle Devonian limestone near Linden has been found, where it disappears below the post-Variscan strata. Ahlburg has thus already put this "horst region on the south-eastern margin of the Lahn Syncline" in relation to the "horst region of the Hörre" (Kegel, 1922, p. 64). This results in the remarkable picture that the Lahn Syncline is accompanied not only in the north, but also in the east by areas of the Lower Harz facies which, like extraneous matters, penetrate into the area of the normal facies of the Lahn-Dill Syncline. In my opinion one must, at least, consider the question of whether the apparent horst regions on the northern margin of the Lahn Syncline and the region near Giessen are trapped remains of klippes.

I would assume that the thrust stacks of Günterode and Eisenroth to the north of the Hörre are still part of the thrust system (II B), which corresponds to their Hercynian Devonian facies.

The question as to whether the Hörre Greywacke, which is recognized as Culm, belongs to the suggested klippe area or to its underlayer cannot be discussed here.

The conditions are complicated in the Lahn-Dill area by the fact that the entire systems of strata are affected by an intense stacking. This is the case, for example, of the Deckdiabas Thrust Fault, the margin of which overlaps the southern part of the Hörre Culm (Kegel, 1922).

Of course there are so many problems in the tectonically and stratigraphically unusually difficult areas, as we find them in the Lahn and Dill areas, that it would be a mistake to come up with a new interpretation without further ado on 
the basis of the work to date. One will have to wait patiently for what the field observations will bring. But these questions must be raised now. As I think, in the whole of the mountain range from the Harz to the Lahn area, the aforementioned references are so closely combined that one can see here an argument for the justification of the pronounced chain of thought.

As has already been said in the discussion of the Sauerland-Upper Harz Zone, the fold axes rise somewhat higher in the Rheinisches Schiefergebirge than in the Harz. It is thus in agreement that the continuation of the comparatively coherent Lower Harz Nappe, perforated only by a few windows, is merely reduced to narrow ridges. According to the above interpretation, the Sauerland-Upper Harz formation, which we saw in the Lower Harz only in the form of the windows mentioned, now forms the widespread folds and imbricate thrust stacks of the Lahn-Dill Syncline. If we follow the mountains still further to the south-west to the Rhine, not only the last klippes of the apparent horst zone have disappeared, but also the Culm and younger Devonian strata of the Lahn-Dill Syncline. We are located in Koblenz in a wide synclinal region, which is complicated by isoclinal folding (Fuchs, 1907), of the Lower Devonian Koblenz beds, which here separate the Siegen Syncline from the Hunsrück-Taunus Zone.

The question as to how the above-tried reinterpretation of Ahlburg's horst or klippe zone is related to the phenomena indicated by Gerth from the Taunus Mountains in 1910 must remain open for the time being. Gerth (1910) has argued that in the Taunus large thrusting have taken place, which have brought the old Devonian Taunus Quartzite widely into the hanging wall of younger Devonian strata. He assumes a subsequently folded Taunus Nappe, under which here and there the covered sequence is exposed in the form of windows. Gerth (1910), whose view has recently been counteracted (Michels, 1926), has, in my opinion, the merit of having been brought up one of the most important problems in the formation of the eastern Rheinisches Schiefergebirge.

Leppla (1925), on whose work cand. Geol. Gellert recently drew my attention to, has found in profiles of the Saar in the continuation of the Taunus Zone to the west of the Rhine still relations, which, with all cautious restraint, he interprets as the thrust margin of the Taunus quartzite. Further north, on the northern margin of the Hunsrück slates against the higher Lower Devonian, thrust faults are known, and it may well be supposed that the Middle Devonian of Olkenbach at the east end of the Triassic Bay of Trier does not owe its preservation to a mere depression. The Rhine profile shows isoclinal folding where the Koblenz Syncline at Goarshausen crosses, which in principle are reminiscent of the imbricate thrust stacks structure of the Lahn area (Fuchs, 1907). Many tectonic features are still to be expected.

One can sometimes read that the Variscan Mountains were much more denuded than the Alps, that those upper thrust nappe masses, which occupy such a broad area in the lat- ter, are eroded to the root. This is certainly not the case. The Variscan Mountains are, to this day, not at a substantially different denudation level than at the Rotliegend time, which is at the end of the folding. They are scarcely as deeply eroded as the Alps would be if the present-day valley floors were taken as a denudation surface. However, if so, the upper Alpine thrust nappe series, e.g. those of the northern Limestone Alps, would not have disappeared yet.

On the whole, the tectonic main structure of the Rhenohercynian zones of the Variscan Mountains from the Rhine to the Harz provide the following order.

II A. Sauerland-Upper Harz Zone, predominantly with quite clear folds and thrust stacks of Devonian and Culm strata.

II B. Lower Harz Nappe, pushed upon II A. It consists of all strata from the Silurian up to the Culm and rises to the west, so that in the border region between Lahn and Dill syncline we find their last imbricate stacks in narrow remains, which were still preserved from the denudation.

II C. The Stieger Nappe of the southern Harz, consisting predominantly of Devonian and Culm and interpreted as a far advanced southern hanging wall of II B. Their western continuation is at times unknown, if it is not to be found in the southern margin of the Taunus.

None of the Rhenohercynian mountain zones enters the area of Saxony. They all pass far in the north of the country. Only the next interior of the large Variscan mountain units is involved in the formation of the Saxon underground, and here it even reaches its typical appearance, so that Eduard Suess was able to borrow the name of the entire mountainous system from the Vogtland.

\section{The Thuringian-Erzgebirge zones (Saxothuringian Zone of Kossmat)}

The type of relation between the southern margin of the greywacke belt and the nearest interior mountain ranges is not known. Both south of the Hunsrück-Taunus, and south of the Harz, the old mountains have been sunk and covered by younger strata. From the fragments, however, which are visible at a short distance from the break-off edge, we see that a crystalline basement passes through here. We see some of these in the Kyffhäuser, in the north-western Thuringian Forest, in the Spessart, Odenwald, and finally in some summits at Albersweiler, west of the Rhine.

With regard to the tectonic relation of this crystalline region to the greywacke belt, it may be assumed that this is not a simple appearance of the deeper rock groups. The studies of Schriel in the area of the southern Harz have shown that the so-called Stieger Series dips southward under the Culm, and that the greywackes of the latter are pushed to the north along shear planes. As a part of gneisses and of mylonite 
granites is already lying south of the margin of the Harz, at the Kyffhäuser hillside with the floodplain of the Goldene Aue, I suspect the hypothesis that this crystalline zone had been pushed towards the submerged Paleozoic series of the Harz from the south, and that the abovementioned shearing phenomena in the hanging wall of the Stieger Series are related to this assumed thrusting of the crystalline rocks of Zone III.

The best insights into the structure of Zone III are obtained in the Thuringian-Erzgebirge region, according to which this unit can be appropriately named. We are concerned here with a seemingly concordant series of rocks, the basal parts of which consist of different types of gneiss. They are followed by muscovite-rich mica schists and phyllites with occasional intercalations of various other metamorphic sedimentary rocks and of lenses of various amphibolites. Without passing a sharp border, one comes from the upper parts of the metamorphic series into the Cambro-Silurian clay-slate group and into the Silurian; in the upper section of the latter the graptolite-bearing alum slates and lydites form an important marker horizon. The hiatus of the Lower Devonian is not noticeable by any conspicuous angular discordance. The Middle and Upper Devonian, which are characterized by numerous diabase intercalations, are followed by Culm slates and greywackes, which are still involved in folding. Only in the progressively coarser formation of the higher Culm strata is the approach of the mountain-forming process expressed. The main folding was at the end of the Culm; but a weaker phase occurred within the area of the Erzgebirge in the transitional period between Waldenburger and Saarbrücker level. The Asturian, Saxon and Palatine phases show only the ending of the movements. The intrusion of the large granite batholiths probably took place in the main area towards the end of the earlier stages of mountain formation.

It would be an unnecessary repetition if the structure of the Saxothuringian fold region was discussed here. For this reason, reference should be made to the overview in the Geologie von Sachsen (Kossmat, 1925a), Johannes Walther's Geologie von Thüringen, as well as to the new publications of the Thuringian Geological Society. The crystalline basement of the Saxothuringian Zone is exposed in three large saddlelike regions.

III A. The northernmost is the zone Kyffhäuser-western Thuringian Forest. In the latter, the gneiss-mica schist region of Brotterode and Ruhla, which is intruded by granite, is worth mentioning. The connection with the gneiss and mica schist area of the Vorder-Spessart is indicated by crystalline xenoliths in the basalt near Fulda. The Böllstein Massif in the eastern Odenwald, with biotite gneisses, muscovite gneisses, mica schists, and marbles, also belongs to this zone (Suess, 1926, p. 99, 191). The western Odenwald has a different character with its mica schists, its contact-metamorphosed old Paleozoic sediments, and the various basic to acidic plutonites. F. E. Suesss has pointed out major tectonic problems here, but the extent of the crystalline basement is too much interrupted to allow for far-reaching conclusions.

III B. The second large saddle-like region of Zone III in the Fichtelgebirge and Erzgebirge region offers much better information. In the latter it has been shown that the seemingly simple dome structure of this "saddle zone" contains very complicated structures. The gneisses and their slate cover are tectonically intermixed by tangential sliding movements and intercalated with each other to form an "onion-shell structure". The structure is reminiscent of the Penninic basement tectonics of the Alps (Kossmat, 1925a).

These tectonic movements took place in the depths of the mountains, and were accompanied by the recrystallization characterized by abundant muscovite formation, which are called "lepidoblastic". But the central gneiss cores remained deeply connected with the magmatic region, because we can see in the Erzgebirge near Fleyh, Bobritzsch and other localities, as well as in the Fichtelgebirge, as the last intrusions in the domed area still granites, which have lasted the folding process in the liquid phase. The Erzgebirge may well be described as a "nucleus autochthonous". However, because of tangential movements the hanging wall of the gneiss dome, as already mentioned, has been metaphorically speaking drawn-out into flags. Certainly the seemingly concordant slate cover in the roof of the gneisses has also undergone considerable tangential movements.

On the basis of the tectonic experiences in the Erzgebirge, it must be assumed that the crystalline basement has also experienced similar stresses in the Spessart-West Thuringian Zone. We are in the area of "Wander tectonics", as Franz Eduard Suess calls it.

The relatively small granite dome, which is visible north of the Erzgebirge as the core of a wide anticline, has a special position under a strongly fragmented gabbro and a metamorphic slate cover. The latter has moved tangentially to the core and, like the peripheral parts of the granulite, shows traces of this stress in the form of lepidoblastic recrystallization. The granulite core itself, however, has a texture which, according to Scheumann (1925) and myself, points to syntectonic intrusion, i.e. to a solidification of the granulite with simultaneous tectonic stress.

Franz Eduard Suess considers the granulite as an outlandish element in the area of Zone III, of course. He suspects that it came from the area of the Moldanubian intrusion tectonics, and that it had come to its place by thrusting over the Erzgebirge. On the other hand, I regard the Granulite Massif as a nucleus autochthon and as a particular intrusion stage at the time of folding. The connection with the magma source remained beyond the latter, because the granulite is everywhere intruded by young granites, which are connected to it, but did not solidify until after the main phase of folding (Philippsborn, 1923; Kossmat, 1925a). 


\section{The thrust nappes of basement block of Münchberg-Wildenfels-Frankenberg and the main region of the Bohemian Massif (Moldanubicum, according to Franz Eduard Suess)}

The occurrences of gneiss massifs in the area of the Vogtland Paleozoic have been so frequently discussed in the literature in the course of recent years that it suffices to refer to them. After Gümbel had already made the observation that the Münchberg Gneiss Massif seemingly superimposed the surrounding Paleozoic, Suess (1912b), on the basis of his investigations, concluded that it is a rootless nappe. The small amphibolite slice of the Wartturmberg, which is isolated from the main massif, overlying the Paleozoic at Hof, contributes significantly to supporting this view. The new work of Wurm (1926) confirmed the opinion of Franz Eduard Suess and provided further arguments for the existence of a tectonic klippe which is to be found south of the Fichtelgebirge dome at the northern margin of the Bohemian Massif. Similar considerations also apply to the small Wildenfels Gneiss Klippe and to the Frankenberg Zwischengebirge ${ }^{17}$ (Scheumann, 1924; Kossmat, 1925a), whose gneiss and amphibole rocks occur completely isolated in the middle of the Paleozoic syncline, which separates the Erzgebirge and Granulite Massif from each other.

An interpretation of these occurrences as "piercing" gneiss horsts is opposed to quite similar reasons, as at that time induced the Alpine geologists to reject the interpretation of the Swiss klippes as local ridges and to recognize the rootless character of these nappes. There are undoubtedly quite tremendous processes, as the distance from the tectonic klippes to the source region, namely the border of the central Bohemian Massif, is to be estimated with at least $50 \mathrm{~km}$. This circumstance was probably the most important reason for restraint against the interpretation of the Münchberg Klippe given by Franz Eduard Suess.

In the Frankenberg region, the margin of the thrusting must have reached the Erzgebirge Basin at the end of the Culm, as the conglomerates of the Waldenburg beds (the so-called Upper Culm of Hainichen and Berthelsdorf near Chemnitz) are already transgressive over the western margin of the tectonic klippe. They have, however, still experienced together with these bending and faulting. It is of interest that the post-tectonic granite intrusion of the Eibenstock Massif in the western Erzgebirge from the Moldanubian gneiss region transverses through the zone of thrusting up to the Erzgebirge. Similarly, in the Harz, the Brocken Granite has also penetrated the thrust plane.

\footnotetext{
${ }^{17} \mathrm{~T}$ : The term Zwischengebirge (Zwischen-Gebirge in the German original) was coined by Suess $(1909$, p. 435). This term is often translated into English as median massif, intermediate range or betwixt mountains, with betwixt mountains (Collet, 1935, p. 24) being the best translation. For convenience, throughout the text the German word is preferred instead of the English term.
}

A description of the Moldanubian core area of the Bohemian Massif would only be an excerpt from the representation of Franz Eduard Suess. It is, therefore, only to be pointed out briefly that here biotite gneisses of the deeper basement (catogenic gneiss), in association with numerous highly metamorphosed sediments and mixed rocks, are penetrated by voluminous granite masses. There is a highly complex structure in the gneiss area, which often follows the outline of granite batholiths. Franz Eduard Suess describes the whole phenomenon as intrusive tectonics and sharply contrasts it with the wander tectonics, i.e. the thrusting structures of the basement of the Erzgebirge-Thuringian Zone (Suess, 1926).

The tectonic separation between the Erzgebirge and Central Bohemian Massif is also strongly expressed in stratigraphy. In the latter, as is well known, the Algonkian and old Paleozoic series of strata of Central Bohemia occur in a large folded syncline. It is very important that in this region the Middle Cambrian and Lower Silurian discordances are preserved intact. In the Erzgebirge-Thuringian Zone, on the other hand, these discordances are clearly blurred by the intense tangential movement under great strain, so that one can see a concordant profile from the crystalline basement to the old Paleozoic in the Erzgebirge.

In the facies of the Cambrian, in the calcareous Upper Silur and Devonian facies, as well as in the fossil content, the Central Bohemian sequence shows many fundamental differences compared to the Vogtland-Thuringian sedimentary sequence. It furthermore already finishes with a plant-bearing upper Middle Devonian. It is evident that the early Variscan movements have already been active in the Upper Devonian, and have increased in the Culm to the prominent thrust movements ${ }^{18}$.

It is difficult to answer the question of how the crystalline zones of Saxony and Franconia continue to western Germany. The mighty Erzgebirge and Fichtelgebirge dome seems to disappear under its slate cover.

The latter closes very clearly around the Fichtelgebirge dome. Even this circumstance implies that the Black Forest and the Vosges, i.e. the so-called Upper Rhenish horsts, already belong to Zone IV, i.e. the Moldanubicum. Eduard Suess has already expressed this view, and in doing so he was guided by the phenomena of intrusive tectonics, which in the two Upper Rhine massifs, as in the central Bohemian Massif, are of similar prominence. Inevitably, the continuation of the Moldanubic type into the French Central Plateau, which has many parallels with the central Bohemian Massif, happens via the Vosges.

\footnotetext{
${ }^{18}$ Only on the western margin of the Münchberg Gneiss Massif has Adolf Wurm found in the extremely complicated tectonic slices a facies of the old Paleozoic which is reminiscent of that of the Central Bohemia, which he describes as "Bavarian facies". According to his observations, it appears that these are beds which have been detached from their underlayer and dragged at the thrust front.
} 
For the time being, there is nothing to be sure about whether the Moldanubian Thrust is present in the Upper Rhine massifs. It is important that in the Vosges the old Paleozoic Steiger and Weiler slates dip under the gneisses of the Urbeis area, and so abruptly that one can think of the continuation of the Moldanubian Thrust over the extension of the Vogtland-Thuringian Paleozoic. It is questionable whether the displacement is as great as that in the area of the Münchberg-Frankenberg tectonic klippes. It might well be that the amount of thrusting here is less. This would perhaps reconcile the fact that the Culm (which lacks the actual Moldanubian territory) plays a similar role in the Black Forest and in the Vosges, as in the northern border mountains of the Bohemian Massif - as in the Erzgebirge and in the Sudetes. To the latter particularly reminiscent is in the Vosges and the Black Forest the prominent Culm discordance above folded basement, perforated by batholiths. The discordance is undoubtedly connected with the proximity of the axial region of the Variscan Mountains, in which the pre-Culm movements were much stronger than in the outer belts.

\section{B. The eastern part of the Variscan arc}

\section{The Upper Silesian-Polish coal field}

This represents a broadly developed syncline, which only occasionally shows a slight overturned folding, which is directed towards the centre of the syncline, but only at the western margin; otherwise, it has very simple tectonostratigraphic conditions. We are here again in the former margin of the Variscan Mountains. The Culm and Devonian folds rise up in the Nízký Jeseník ${ }^{19}$ Mountains, while the Lower Carboniferous limestones of the Kraków region and Devonian strata, which are closely related to those of the Kielce Mountains, are already found in a relatively simple tectonostratigraphic position, outside the eastern margin of the hard coal region. We must already consider the north-westerly-striking folds of the Cambrian, Silurian, and Devonian of Kielce as a zone of folds of the Russian region lying outside the actual Variscan system.

The question of whether the coal deposits in the subsurface of the northern German lowlands continually pass to the north-western section of the coal belt, the last of which we are acquainted with at Osnabrück, has not yet been decided with the inclusion of the Upper Silesian-Polish Coal Basin to the marginal belt of the Variscan Mountains. The marginal basin will not have the same width and depth everywhere. It may have been narrowed where the protruding Variscan arch approached the border of the rigid northern European continental region, so that the Carboniferous zone may have been displaced here, or may have fallen victim to later denudation. Originally, however, there would probably have been a coher-

\footnotetext{
${ }^{19} \mathrm{~T}$ : Nízký Jeseník is the Czech name for a mountain range of the eastern Czech Republic. The German name is Niederes Gesenke.
}

ent belt of deposits, which is still known in western Asia. The Carboniferous on the north-eastern coast of Asia Minor has striking features in common with our Carboniferous in the foreland basins (Wilser, 1927), especially when one considers that in a southerly adjoining zone of the Bosporus region the Devonian shows a Rhenish character.

\section{The East Sudetic Greywacke Zone}

In southern Moravia, between Brno and Weißkirchen, the Sudetes area of the Nízký Jeseník Mountains emerges from the young deposits of the Carpathian foreland. With northeastern to north-north-eastern strike, it stretches only to the extent of the broad Oder plain of Silesia; then, it remains buried under the deposits of the lowland, only covered by the expanded deposits of the March valley near Olmütz. Within this Devonian and Culm belt there is a complicated structure of folds, on which the sheets of the Austrian geological special map, recorded by Emil Tietze, Gejza von Bukowski, and Leopold von Tausch, shed light. Under the Devonian, the basis of which is constituted by conglomerates in different places, an old basement consisting of phyllites, amphibolites, and perhaps gneisses appears in places, for example, on the map sheet of Olmütz (Tietze, 1893). From the northern part of this Sudetes Zone, Bederke (1925, p. 104) mentions the occurrence of gneiss pebbles in the foliated Lower Devonian conglomerates near Dürrseifen west of Engelsbach and near Ober-Grund south-west of Zuckmantel.

These important observations from different parts of the Eastern Sudetes Devonian zone prove that the Variscan folding has here affected a region which had already been influenced by the Caledonian orogeny. In many respects one can remember the circumstances of the Brabant horst in the foreland of the West Variscan mountain section. The Devonian discordances in the Ardennes also belong to this group of phenomena.

The relations in the area of the Brno Granite-Syenite intrusions are still unclear. Here the geological mappings show a coarse clastic basal formation of the Devonian, reminiscent of Old Red, above the plutonic basement. Contact metamorphic features do not exist. New investigations, however, have to show whether the boundary here must be regarded as an original superposition over a pre-Variscan basement, or as a shear plane, as Franz Eduard Suess is inclined to accept (Suess, 1926, p. 228).

\section{The boundary between the East Sudetic Greywacke Zone and the Moravian-Silesian Unit}

In the west, the zone of the non-metamorphic Devonian strata of the Nízký Jeseník Mountains adjoins intensively tectonized crystalline rocks of the Moravian-Silesian Zone, as its investigator Franz Eduard Suess called it. While in the West Variscan section we can nowhere see the con- 
tact between the Greywacke Zone (II) and the crystalline belt of Spessart-Kyffhäuser (Zone III), the boundary of the Moravian-Silesian region is considerable and promises many interesting discoveries on tectonic questions. It should be mentioned that Bukowski records irregular blocks of Silesian chlorite gneiss in the region of the steeply dipping folded Devonian in his mapped sheet Mährisch-NeustadtSchönberg (Bukowski, 1905). The nature of the occurrence of these blocks, which are partly folded but irregularly crossing the strike of the Devonian, and which not infrequently rest upon Devonian on a longer stretch, does not, in my opinion, speak of saddle-like structures, but of trapped tectonic klippes.

The boundary between the well-known Würbental Lower Devonian quartzite and the crystalline basement of the Altvater is, as Franz Eduard Suess pointed out, not a simple superposition, but shows strong tectonic disturbances (Suess, 1912a). Bederke also describes conspicuous planes of movement on the eastern boundary of the Altvatergneis, but emphasizes that the latter must have already formed the basement of Devonian deposits and had pre-Devonian metamorphosed (Bederke, 1925, p. 104).

Franz Eduard Suess summarizes his impressions of the nature of the western boundary of the Devonian and Culm region in the following manner: "If we consider the SilesianMoravian structure in its larger contexts, it is seen that the non-metamorphic Devonian is widely spread under the Culm of the outer zone, but that it then engages under the thrust nappe, and has best preserved its non-metamorphic character, where it forms the base of the pushed up Moravian nappes" (Suess, 1926, p. 232).

A closer tectonic comparison of the Devonian-Culm zone of the Sudetes with the individual units of the West Variscan Rhenohercynian zones in the Harz and the Rheinisches Schiefergebirge is, of course, excluded. It seems almost impossible that individual folds and thrusts, though they may be so major, can be traced to such a distance.

The narrow width of the greywacke belt is striking in the Sudetic section, compared to the wide expansion in the West Variscan area. One is reminded of the phenomena in the Carpathian arch, where the Flysch Zone, which is broadly developed in the main section of the Carpathians, narrows further to the east, and is almost overwhelmed by the crystalline zones that penetrate the interior. This is especially the case where the mountains bend back with a sharp turn to the Danube Gorge area at the Iron Gates. One can almost compare the Sudetes loop with this Wallachian loop.

\section{The Moravian-Silesian Zone and the Lugian Zone}

Moravian-Silesian Zone. The Moravian Zone recognized by Franz Eduard Suess on the eastern margin of the Bohemian Massif as a special tectonic unit decays in length into a Thaya dome near Znaim and into a Schwarzawa dome at Gross-Bittesch. According to Franz Eduard Suess, it is "a mountain for itself", of Alpine nappe structure, indeed in a dome-shaped arrangement.

The Moravian hanging wall is the sericitic "Bittescher" augen-gneiss, which is matched to the parallel structure of the Moldanubian mica slate (see Zone IV) with a concordant assembly and is surrounded and overlain by them. At the core of the dome, the Thaya batholith emerges, which becomes flaser gneiss at the margin, similar to the Zentralgneisses of the Alps. Between the core batholith and the Bittescher Gneiss Nappe, metamorphic sediments, namely, slate, greywackes, quartzites, and grey limestones, are intercalated, which are interpreted as a modified Devonian. Their metamorphic grade ranges from phyllitic to the formation of garnet and staurolite-bearing mica schists. The entire zone belongs to a shallower depth of metamorphism than that of the Moldanubicum which has been pushed up. The latter is to be assigned to the deepest basement in central Europe.

To the north of the Moravian Zone through the embedded Rotliegend of Mährisch-Trübau-Boskowitz appear rock assemblages of a similar character only on the left side of the Morava River and form the high, north-northeast striking Hrubý Jeseník ${ }^{20}$ Mountains, which continues into the area of Freiwaldau. Significant traces of this zone are observed in the hills of the Rummelsberg Group, which rise north of the young Sudetic Marginal Fault, east of Nimptsch in the form of mica schists, quartzites, crystalline limestones, and amphibolites. This is the "Silesian Zone" of Franz Eduard Suess.

Completely open is the question of where the equivalent of the Moravian-Silesian Zone is to be found in the western part of the Variscan arch. It is not impossible that a metamorphic equivalent of the innermost regions of the Rhenohercynian belt will appear.

Lugian Zone. ${ }^{21}$ In the west, the Silesian Zone, from Buschin in Moravia to Friedeberg in Silesia, descends along the so-called Ramsau Line near Goldenstein under the crystalline region of the Králický Sněžník ${ }^{22}$ Mountains, which belongs to the Lugian system of Franz Eduard Suess. The strike here is north-northeast, but it bends into the northnorth-westerly direction near the Sudetic Marginal Fault, which, in my opinion, shows the tendency of incorporation into the arc. On the Ramsau Line near Goldenstein, slate-like phyllites and non-metamorphic limestones of the Silesian Zone dip below coarse-grained garnet-bearing mica schists of the Králický Sněžník Mountains, so that the con-

${ }^{20} \mathrm{~T}$ : Hrubý Jeseník is the Czech name for a mountain range of Eastern Sudetes in northern Moravia and Czech Silesia. The German name is Altvatergebirge or Hohes Gesenke.

${ }^{21}$ Named after the tribe of the Luger in Tacitus (Suess, 1926, p. 4).

${ }^{22} \mathrm{~T}$ : Králický Sněžník is the Czech name for a mountain in the Eastern Sudetes. The German name is Glatzer Schneeberg or Spieglitzer Schneeberg. 
trast is particularly striking. Further north, this does not seem so much the case, since on both sides of the tectonic line garnet-mica schists with intercalations of two-mica gneisses are mentioned.

"The prominent rocks of the Králický Sněžník Mountains are two-mica gneisses (Rosiwal's red gneisses), also muscovite gneisses, mica schists and gneiss mica schists, graphite layers, very diverse hornblende rocks, partly epidote or augite bearing, and crystalline limestones, as well as ridges of biotite gneiss in the area from the Morava valley near Platsch, northward, and in the place cited. It is almost the whole irregular mixture of diversity of Moldanubian rocks" (Suess, 1926, p. 151). Franz Eduard Suess considers this series to be the foothills of the Moldanubian Plain, partly with lepidoblastic foliation (Suess, 1926, p. 240).

I must say, however, that this rock formation, in which the gneiss also plays a part, reminds me much more of the petrographic composition of the western Erzgebirge in the surrounding area of Wiesenthal.

The lepidoblastic foliation with abundant muscovite formation also characterizes this region and distinguishes it following Suess from the Moldanubicum.

The character of the Paleozoic in the Lugian section of the Sudetes has, I believe, very much to say. In the crystalline region of the Králický Sněžník, the Glatzer region, with its phyllites, its Silurian alum slates and lydites, its diabase for which Bederke (1924) assumed a pre-Devonian age - its fossil-bearing Upper Devonian, and its Culm strongly remind one of the Vogtland-Thuringian facies. The appearance of the Paleozoic in the Bober-Katzbach mountain range, which lies on the northern margin of the Western Sudetes, which is still in the Lugian area, also agrees with this. The difference with the Moldanubian Paleozoic with its calcareous Upper Silurian-Devonian beds is so profound that the question as to whether the Lugian mountain section has closer relations to the Saxothuringian Zone (III) or the Moldanubian Zone (IV) is also from this point of view to be answered in favour of the first.

The crystalline rocks of the Eastern Sudetes belong together with those of the Western Sudetes to one and the same "Lugian" basement regions. They are, as Suess (1926, p. 122 and 136) emphasized, connected with them. From the crystalline belt, which encircles the eastern Krkonoše ${ }^{23}$ Mountains, units depart to the south-east, which unmistakably continue in the "Bohemian ridge" (Adler and Habelschwerdter Gebirge), which is already part of the Eastern Sudetes.

In my work of 1925 (Kossmat, 1925, p. 353, 354), I have remarked as follows about the connecting region between the Western Sudetes and Eastern Sudetes: "In the Middle Sudetes, the crystalline basement plunges down relatively deeply. As long as the connection can be found below the

\footnotetext{
${ }^{23} \mathrm{~T}$ : Krkonoše is the Czech name for a mountain range in the north of the Czech Republic and the south-west of Poland. The German name is Riesengebirge.
}

transgressive overlying Carboniferous-Dyas-Upper Cretaceous strata, it may be assumed that a narrow strip of gneiss and mica schist in the south-easterly direction, from the crystalline slate belt, forms the connection with the Adler and Habelschwerdter Gebirge. In the further course, the latter is connected with the extended basement uplifts of the Eastern Sudetes ("Hrubý Jeseník")."

\section{The Moldanubian Nappe of Góry Sowie ${ }^{24}$}

"To the north of the Habelschwerdter gneiss-mica schist's ridge, phyllites and Silurian-Devonian strata must occupy by far the largest part of the subsurface, because they are exposed in the north-west and north of Waldenburg, as well as in Glatz, surrounded by transgressive overlying younger strata. Here, therefore, lies the deepest depression of the old fold zone, dividing it into a western and eastern Sudetic section.

It is therefore all the more striking that in this synclinallike depression the gneiss massif of the Gory Sowie rises like an island pointed to the west. In very small, often scarcely $1 \mathrm{~km}$ distances from the margin of the gneiss, unaltered Silurian slates and calcareous beds of Upper Devonian strata (e.g. at Oberkunzendorf, Adelsbach, Ebersdorf, and Herzogswalde) occur in the north-west and south-east and continue into the Glatzer Kessel.

The immediate contact with the gneiss is covered by a conglomerate with Productus giganteus (upper stage of the Lower Carboniferous). It is local to the heights of the Eulengebirge, and is evidently similar in structure to the conglomerate of the Hainichen-Berthelsdorf beds in the Frankenberg region. The age difference is certainly not big: it is about the time span of the upper Lower Carboniferous to the lower Upper Carboniferous.

If we consider the whole layout, we have the presumption that the Góry Sowie occupies an analogous position in the mountain structure, like the Frankenberg-WildenfelsMünchberg Gneiss Klippes" (Kossmat, 1925b, p. 354).

In this view of the Góry Sowie, Suess and I agree absolutely, and have expressed this idea independently of one another. The question now is whether the crystalline region of the Králický Sněžník Mountains of the Eastern Sudetes, which was pushed up onto the Silesian Zone along the Ramsau Thrust Fault, is to be regarded as an area lying below the Góry Sowie, but also a Moldanubian Zone, or as a Sudetic partial nappe. From my point of view, the important facts, especially the description of their composition of rocks by Franz Eduard Suess and their connection with the relatively autochthonous Krkonoše crystalline and the facies of their Paleozoic, are decisive for the latter interpretation.

\footnotetext{
${ }^{24} \mathrm{~T}$ : Góry Sowie is the Polish name for a mountain range in the Central Sudetes in south-western Poland. The German name is Eulengebirge. The English name Owl Mountains has not been used here.
} 
More recently, the view was expressed (Zimmermann, 1924; Schindewolf, 1925, p. 84ff.) that on the northern side of the Gorry Sowie the gneiss-bearing conglomerates with the accompanying greywackes do not correspond to the Culm conglomerates with Productus giganteus, which lie above the gneiss at Silberberg, but belong to the upper Devon. The Góry Sowie ought to have already taken its present position in the latter period. The other tectonic arguments, which speak for the rootless character of the Góry Sowie, are, by the way, likely to be around for the foreseeable future.

It seems to me that the reasons given are not valid for the revision made in the age assignment. Coarse conglomerates, such as those in the limestone graben near Alt-Liebichau, which, besides Góry Sowie gneisses and other rocks, also include Upper Devonian Sphaerocodium Limestone (Schindewolf, 1925) and thus look similar to the real Culm in the wider surrounding, are very suspect. The narrow tectonically disturbed parts of fossil-bearing Upper Devonian slates, which appear to be intercalations, and which gave rise to the new conception of the age assignment, give me the impression that they are pushed-up thrust slices of the substrata.

Zimmermann has now placed on the map of Schweidnitz the entire, several-kilometre-wide range of the greywackes and conglomerates mentioned in the vicinity of the Kunzendorfer limestone quarry (Zimmermann, 1924, p. 17, 26), on the grounds of strike and dip, in the Upper Devonian, and writes: "If this is the case, then the Schweidnitzer Upper Devonian has a petrographic character which up to now has not been known either from Silesia or elsewhere from Germany, and has, therefore, an exceedingly great thickness, which is, perhaps, 1100 m" (Zimmermann, 1924, p. 17).

Now the following is to be considered: The conglomerates and greywackes, which appear to lie below the Sphaerocodium-bearing, fossil-rich Kunzendorfer Limestone, and are designated as the lowest Upper Devonian by Zimmermann, extend to the west in uninterrupted manner in the map sheet of Freiburg. They pass via Liebichau into the area of Fürstenstein, whose rocks are still left as Culm for good reason by Bederke (1924, p. 39), while consequently Zimmermann must place them to his lowermost Upper Devonian. Now, in the Fürstenstein conglomerate near settlement Zeisberg (Dathe and Zimmermann, 1912, p. 45), there are pebbles of granites and gneisses, and many other rocks, also pebbles of limestones with frequent remnants of Clymenia laevigata, that is, a fossil of the very high Upper Devonian. If all these facts are held together, then I must conclude that there are internal contradictions, the solution of which must be unconditioned before giving up the idea of the Culm age to which former geologists have been lead, and an Upper Devonian pseudo-Culm in this part of the Sudetes accepts.

In addition, the possibility of assuming that it is a conglomeratic deposit of the Wocklumeria and the Gattendorfia zone of the uppermost Devonian (in the classical outcrops not more than a few tens of metres thick) would not eliminate the contradictions mentioned above, as the stratigraphic assign- ment of the conglomerates in question to the Upper Devonian is based on the fact that they are apparently intercalated with Buchiola slates of the lower Upper Devonian.

I also briefly discussed the above questions occasionally at a geological colloquium in Halle in November 1926.

\section{The relationship of the Lugian Zone with the Erzgebirge region}

A question of great theoretical importance is the relation of the Lugian part of the Sudetes to the Erzgebirge. It was always clear to the Saxon geologists that, at the critical point where both systems come together, there is no turning from one to the other, but an important tectonic truncation takes place here. Hermann Credner always strictly distinguished an Erzgebirge and a Lusatian province in Saxony. He drew the boundary of both on the south-western side of the Elbtalschiefergebirge. The gneiss domes of the north-eastern Erzgebirge suddenly disappear at the NossenTharandt-Gottleuba Fault (Middle Saxon Thrust Fault after Pietzsch, 1917) and are completely abruptly bordered by the old Paleozoic strata of the Elbtalschiefer system intruded by granitic and syenitic magmas. It is clear that this zone continues south-eastward under the transgressive Cretaceous. It is exposed in the Elbe gorge north of Tetschen, and must continue in the subsurface to the crystalline and old Paleozoic slate zone of the southern side of the Krkonoše Mountains. Franz Eduard Suess therefore rightly connects it with his Lugian system. On the other hand, there can be no doubt for the Saxon geologist that in the north-west near Walsdruff and Döbeln the Elbtalschiefer Zone is associated with the slate cover of the Granulite Massif, which is part of the Erzgebirge-Thuringian system, and in the Vogtland, furthermore, forms the cover of the Fichtelgebirge and Erzgebirge.

Franz Eduard Suess has questioned the autochthonous nature of the Granulite Massif and suggested the possibility of being, together with its slate cover, juxtaposed as a tectonic nappe between the Erzgebirge region in the footwall and the Moldanubian Frankenberg Gneiss Klippe in the hanging wall. It would have migrated from the south over the lying folds of the Erzgebirge. According to what was said above about the Elbtalschiefer system, this view would lead to the conclusion that with the Granulite Massif the Lugian Zone of the Western Sudetes was to be regarded as a tectonic nappe system which crossed the Erzgebirge dome and its eastern continuation in the subsurface.

However, I cannot find this approach viable for various reasons. Firstly, there is only the normal VogtlandThuringian stratum, just as we find it above the crystalline basement of the western Thuringian Forest, between the Moldanubian Münchberg-Frankenberg klippes and the domes of the Fichtelgebirge-Erzgebirge region. No cover system corresponding to the slate cover of the Granulite Massif occurs between the Erzgebirge-Fichtelgebirge crystalline 
and its Paleozoic. Secondly, the granulite dome, despite the peculiarity of its petrographic features, which makes Franz Eduard Suess doubt the autochthonous character of this zone, must nevertheless be connected with the autochthonous basement. We see that in the whole granulite dome, with the restriction to this, the "post-tectonic", i.e. after the major movements, Mittweida granites intruded. This is not only the larger dyke stocks of this rock, which are recorded on all maps, but also the numerous branched granite apophyses, of which probably not a single larger granulite exposure is free. This magmatic impregnation, the material of which, according to the investigations of Scheumann and Philippsborn (Philippsborn, 1923), is connected with the granulite, would, in my opinion, be absolutely impossible if the granulite was not "nucleus autochthonous", i.e. if it was not fully connected till the late stages of the folding processes with the original magma source. However, this would have to be excluded if, as a tectonic klippe coming from the south, it would rest above an outlandish stratum.

The West Sudetic mountain range is distinguished by the even more extensive batholiths, namely the Meissen Syenite Granite Massif in the Elbe Zone, the Lausitzer and JizeraKrkonoše Granite massifs beyond the Elbe. Especially the massif of the Krkonoše Mountains, which has ascended in the gneiss and crystalline slate area and has pushed aside large parts, reminds me of the granite mass, which has largely consumed the core of the definitely autochthonous Fichtelgebirge gneiss. To this end we must take into account that the granite poorness of the Erzgebirge is only an apparent peculiarity due to the accidental elevation of the surface of the denudation. If the mountains were cut deeper, the granites of Bobritzsch near Freiberg, Fleyh in Bohemia, and other small occurrences would merge into gigantic batholith regions. In this case, a picture would emerge which, like that of the West Lugian section of the Sudetes, should remind us of the intrusive tectonics of the central Bohemian Massif.

In my view, therefore, in tectonic, petrographic, and stratigraphic relations, there is no reason to take the Lugian Zone out of Zone III and to regard it as a branch of Unit IV, the Moldanubian Zone.

This is not to say, for example, that the Sudetes ridge is the continuation of the Erzgebirge. The crystalline basement of Unit III, the most common feature of which is, among other things, the concordant relation of the gneisses with their muscovite schist cover, which is caused by tangential movements, occurs in the West Variscan section, as we have seen, in several exposures. The Spessart-West Thuringian Zone and the Fichtelgebirge-Erzgebirge Zone represent only special highs of their joint crystalline basement. It seems as if the Fichtelgebirge-Erzgebirge dome as such has no direct continuation either in the west or in the east. It submerges and is replaced by its new, emerging parts of the basement region of Zone III.

The Erzgebirge and Lugian system are, in my opinion, vicarious. If we consider that such tectonic layer repetition as occurs in the domes of the Erzgebirge is not observed in the crystalline schists of the Krkonoše Mountains, I should note, however, that the 2-fold, apparent intercalation of mica schists in gneiss north of the Krkonoše Mountains is also due to strong tangential movement respectively. The alternation of gneiss and crystalline schists described by Berg (1912) in the eastern Krkonoše Mountains reminds me of Erzgebirgetype tectonostratigraphy. The classical dome form of the Erzgebirge region is not visible in the Krkonoše Mountains since the late batholithic intrusions have destroyed too much of the former basement. In this respect, in the Fichtelgebirge, whose affinity, and even togetherness with the Erzgebirge dome, remains unquestionable in the whole situation, is not much better than in the Western Sudetes.

K. Pietzsch has recently investigated the geological conditions in the critical boundary zone between the Erzgebirge and the Lugian sections of the Variscan Mountains. He gives an account of this in Volume 2 of the Abhandlungen des Sächsischen Geologischen Landesamts. In particular, I draw attention to the proof which he produced, that a strong transversal displacement has taken place along the Elbtalschiefer Zone. It has carried the Lugian section considerably towards the south-east in relation to the Erzgebirge. The accumulation of the great masses of batholiths in this section of the mountains is probably also connected with this process. Here, on a large scale, we find transversal disassembling connected with dragging phenomena in the inner part of the Variscan $\operatorname{arch}^{25}$. Similar phenomena on a smaller scale are also to be found within the actual Saxothuringian region itself. Compare, for example, the sigmoidal dragging of the Berga Anticline north of the Kirchberg granite region (Kossmat, 1925a).

It may be remembered that the Lugian Zone, the westernmost of which is very strongly reminiscent of the types of Freiberg we see in northern Saxony near Sageritz and Strehla on the Elbe, is still connected directly with the West Thuringian-Spessartian arching of the crystalline mountains. However, I believe that this combination is not necessary to justify the affiliation of the Lugian system with Variscan Zone III, i.e. with the Saxothuringian basement.

\section{Closing remarks}

If we are entering the coherent Moldanubicum of the Bohemian Massif, which is crowned by a few tectonic klippes of Moldanubian origin, from the Erzgebirge, or from the Sudetic mountain range, we are located in the core part of the Variscan Mountains, for whose appearance Franz Eduard Suess has proposed the term intrusion tectonics. Over Black Forest and the Vosges, this type continues into the French Central Plateau and the southern parts of the Breton Basin.

\footnotetext{
${ }^{25}$ Also in the middle and eastern Harz the tectonic zones show a sigmoidal deflection. It even appears that the appearance of the Brocken and Ramberg granites was linked to it.
} 
We also encounter similar conditions in certain central parts of the Spanish Meseta.

With regard to the facies of the Paleozoic deposits, there are already more southern elements in the middle of the Bohemian Massif. The profile of the central Bohemian Basin from the Algonkian ${ }^{26}$ up to the Middle Devonian has a lot of analogies with the Montagne Noire on the southern margin of the French Central Plateau, especially in the Cambrian and Silurian sections, and with occurrences in the Spanish truncated highland ${ }^{27}$. South of the Bohemian Massif, in the Carnic Alps, we are no longer in the central region of the Variscan Mountains, but already in its southern sedimentary zone, which has continued to the Pyrenees and Asturias. The layer sequences are completed here; we come into the realm of paralic and marine Carboniferous and Permian occurrences, which already indicate the margin of the great Mediterranean of this time. I would like to describe these southern folds of the Carboniferous mountains as Zone $\mathrm{V}$ with the name Paleodinaric belt.

We have thus traversed the area of the Carboniferous mountain range, somewhat similar, as if we were walking through the young mountain range from the Alpine Carpathian foreland to Vienna to the Adriatic. Of course, the southern sedimentary folds of the Carboniferous mountain range are overprinted by the young Mediterranean folding in central Europe. Only in the north of Spain do they still show clear remains of their former fold structure. This is the great value of the beautiful profiles of Asturias, tectonically reminiscent of Dinaric fold structures, which were shown last year during the excursions of the International Geological Congress.

Within Germany we must content ourselves with combining the fragments of the northern to inner zones of the Variscan Mountains, as far as they are visible to us under the younger cover. Despite all the difficulties, despite the fragmentation by the "Karpinsky's" north-western faults, which corresponded to the marginal rupture of the Russian platform, and particularly those of the Sudetes, the great features of the Variscan structure became more and more clear. Isolated island hills and some drill results in the wide flat intermediate area between the eastern and western parts of the arch help this. We find the West Sudetic Silurian quartzite near Görlitz again at Dobrilugk, and we know, from a hole at Dessau, mylonitized granites as a possible link between the Kyffhäuser and the granites of the Western Sudetes. Only the Rhenohercynian zones in the large section between Magdeburg-Zerbst and the outer Eastern Sudetes have so far completely escaped our observations.

\footnotetext{
${ }^{26} \mathrm{~T}$ : The term Algonkian (Algonkium in German) was coined by Walcott $(1889$, p. 383, 384) and officially defined by the United States Geological Survey (Powell, 1890, p. 20, 66). It is used in the older literature as a synonym for Proterozoic.

${ }^{27} \mathrm{~T}$ : A truncated highland is the heavily eroded remains of a fold mountain range. The German term is Rumpfgebirge.
}

An interesting addition to the picture of the Variscan arc is given by the large Upper Carboniferous-Rotliegend troughs, which, with their porphyry eruptions, characterize the final phases of Variscan mountain formation. In spite of the deviations which existed between the relations of this period and those of the main period of the folding, a certain connection with the large arrangement of the mountain chain is not to be overlooked. Born (1921) has shown this in a very clear form. We can see from this that the large Rotliegend trough, which can be traced from the Saar region via Thuringia, western Saxony, and the southern Harz margin, can be found on the basis of individual drill results at Hillmersdorf and elsewhere in the northern foothills of the Western Sudetes (Löwenberg Syncline) and into the Middle Sudetes. In the vast majority of its extent, it evidently adheres to the Saxothuringian Zone, and marks its subsequent decline towards the outer Rhenohercynian Zone of the Variscan Mountains. It is also remarkable that the Moldanubian region, which had been pushed up, was likewise broken down in the hinterland of the Erzgebirge and the Sudetes during the Upper Carboniferous-Rotliegend time. In fact, we see the mentioned Paleozoic continental deposits spreading widely in north-western and north-eastern Bohemia, and continuing as a filling of the Boskovic depression into the region of Rossitz in Moravia (west of Brno). This north-convex, half-moon-shaped, young Paleozoic depression is the distinguishing point between the core of the Bohemian Massif, and the Erzgebirge, as well as the Sudetic boundary fault.

In conclusion, I would like to say a few words about the comparison between the Variscan and Carpathian mountain arch. Such comparisons of mountainous elements of the Earth's crust, which are so far apart, are rejected by many geologists as incautious. Nevertheless, I believe that the analogy between the Variscan arc of the Carboniferous period and the Carpathian Arch of the Tertiary period goes so far that the comparison must be made. The Carpathians formally show us a copy of the Variscan arch, which has been moved to the south-east by 100 geographical miles (Kossmat, 1921, p. 37). The margin of the northern rim, the Carpathian Flysch Zone, which corresponds in many respects to the greywacke belt of the Variscan Mountains, the klippe phenomena, and the crystalline core zones are very similar. The impregnation of the basement with syntectonic and late- to post-tectonic batholith masses has, however, been much lower in these mountains of the Tertiary period. Striking analogies, on the other hand, again offer the internal fracture zones of both the old and young arc and the accompanying volcanic effusions. The trachytes, andesites, and basalts of the inner Carpathian volcanic ridge repeat in great measure what we see in the inner-Variscan porphyry, porphyrites, and melaphyres. The analogies are repeated in the type of sulfidic veins connected to this eruptive phase. In such phenomena deep-rooted laws undoubtedly come to light. We must not, therefore, conclude such comparisons, since, on the basis of considerations of a similar nature, all our experiences are due to the develop- 
ment of the mountain ranges, their relations to geosynclines, and their connections with the magmatic cycles. In this comparative way, we may eventually also expect information on the great problems of crustal movements, especially on the question of the tangential displacements of the Earth's crust.

Data availability. No data sets were used in this article. 


\section{Appendix A: Kossmat's supporting plates}

In a set of supporting plates Franz Kossmat provides a map showing his subdivision of the Variscan Mountains and geological cross sections through important regions of the Variscides. Kossmat refers to these plates in his contribution, but all plates represent an independent part of the Gliederung des varistischen Gebirgsbaues published 1927. Here these plates are reproduced from the original printing. Some brightness and colour adjustments have been made using image-editing software. The explanatory notes to the geological sections (Fig. A4) have also been translated into German.

In the following, the explanatory notes of Fig. A4 are translated into German.
A1 Section through the western part of the Variscan arc

I. Westphalia Zone.

II. Rhenohercynian zones. II A.: Sauerland-Oberharz Zone. II B-C.: western continuation of the Lower Harz Nappe in the eastern Rheinisches Schiefergebirge.

III. Saxothuringian zones. III A.: Spessart-Thuringian Forest Zone. III B.: Fichtelgebirge and Erzgebirge Zone.

IV. Moldanubian region with outliers/nappes.

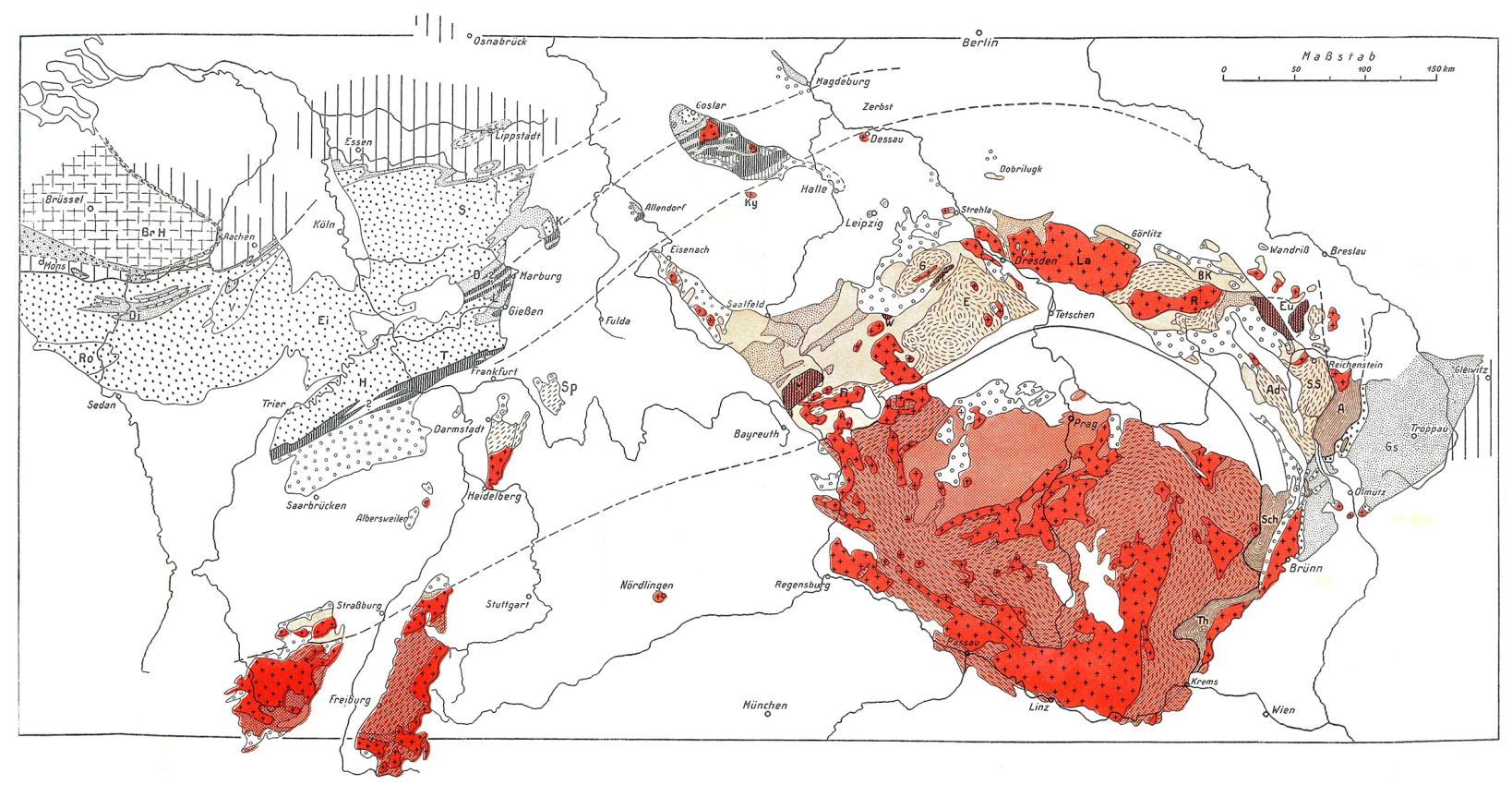

Figure A1. Supporting plate showing the subdivision of the Variscan mountain belt. Explanation of letters in the map: A: Hrubý Jeseník; Ad: Orlické Mountains; BK: Bober-Katzbach Mountains; BrH: Brabant Horst; D: Dill Syncline, Di: Dinant Syncline; E: Erzgebirge; Ei: Eifel; Eu: Góry Sowie; F: Frankenberg Klippe; Fi: Fichtelgebirge; G: Granulite Massif; Gs: Gesenke; H: Hunsrück; K: Kellerwald; Ky: Kyffhäuser; L: Lahn Syncline; La: Lausitz Massif; M: Münchberg Klippe; R: Krkonoše Mountains; Ro: Rocroi Massif; S: Sauerland Anticline; Sch: Schwarzawa dome; Sp: Spessart; SS: Králický Sněžník Mountains; T: Taunus; Th: Thaya dome; V: Venn; W: Wildenfelser Klippe. 
Abbreviations of mountain parts. RK: Ruhr Coal Belt; S: Sauerland Anticline; D: Dill Syncline, H-K: HörreKellerwald Ridge; T: Taunus; RS: Ruhla Anticline; ZM: Ziegenrück Syncline; Fi: Fichtelgebirge; M: Münchberg Gneiss Klippe; Er: Erbendorf Basement Region.

Rock groups. krl: crystalline basement of the Moldanubian region; kr: crystalline basement of the Saxothuringian zones; p: phyllite and phyllitic clay slate; s: Silurian; t: Devonian; cu: Culm; co: Upper Carboniferous; G: granite.

A2 Section of the Granulite Massif through the Frankenberg Klippe to the Erzgebirge. Scale $1: 100000$.

Rock types of the Erzgebirge and Granulite Massif.

gnf: Freiberger Grey Gneiss; gnk: fine-grained-flaky Grey Gneiss; mg: Muscovite gneiss ("Red Gneiss") and flaky Garnet-Muscovite Schist; ga: Gabbro; sp: Serpentine; g: Granulite; Gr: Lagergranite; G: Mittweida Granite.

gg: gneiss-mica schists and Cordierite gneiss; m: mica schist; p: phyllite; pq: phyllite quartzite; px: metamorphic Greywacke; I: trapped meta-lydite (Silurian?).

s: Silurian; t: Devonian; cu: Culm.

Rocks of the Frankenberg Klippe. gna: Frankenberg augen-gneiss; hm: Muscovite-Hornblende Schist; hp: Amphibole-Epidote Schist ("Prasinite Schist").

P: Rotliegend Porphyre and Tuff.

A3 Schematic profile of the Harz Mountains. Scale $1: 100000$. (With use of the Geologic Special map and others)

II A.: Upper Harz Zone: $\mathrm{t}_{l}$ : Lower Devonian; t: Middle and Upper Devonian; $\mathrm{cu}_{l}$ : Culm lydite and clay slate; $\mathrm{cu}_{2}$ : Culm greywacke and slate; $\mathrm{cu}_{1-2}^{t}$ : Tanne Plattenschiefer, lydite and greywacke (here also assigned to Culm).

II B. Lower Harz Nappe. s: Silurian; eg: "Ecker gneiss"; t: Devonian in general.

II C.: Stieger Nappe. st: Stieger Slate and Diabase; $\mathrm{cu}_{1}$ : Culm lydite and clay slate; $\mathrm{cu}_{2}$ : Culm greywacke and slate. Intrusive rocks: ga: gabbro; G: granite.

Postvariscan cover. z-ro: Zechstein and Upper Rotliegend; bs: Buntsandstein; mk: Muschelkalk; k: Keuper; j: Jurassic (Liassic); cr $_{1}$ : Lower Cretaceous.

\section{Westfälische Zone und Vorland.}

Produktives und flözleeres Oberkarbon

ind Unterkarbon und Devon

It十 Silur und Kambrium des Brabanter Horsts

II. Rhenoherzynische Zonen.
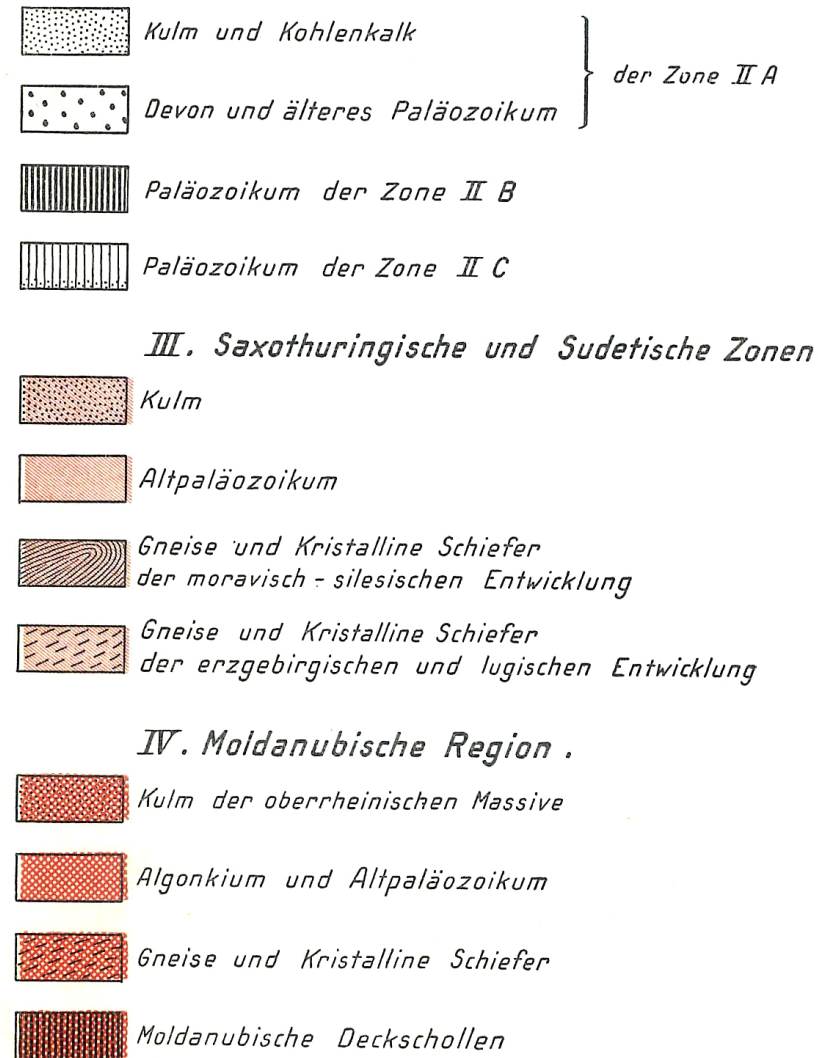

+++ Granitische Batholithen aller Zonen

$\left.\begin{array}{|lll|}\hline 0 & 0 & 0 \\ 0 & 0 & 0\end{array}\right]$ Transgredierendes Oberkarbon und Rotliegendes

Postvaristische Überlagerung (Zechstein bis Quartär)

Figure A2. Explanatory notes to Fig. A1. 

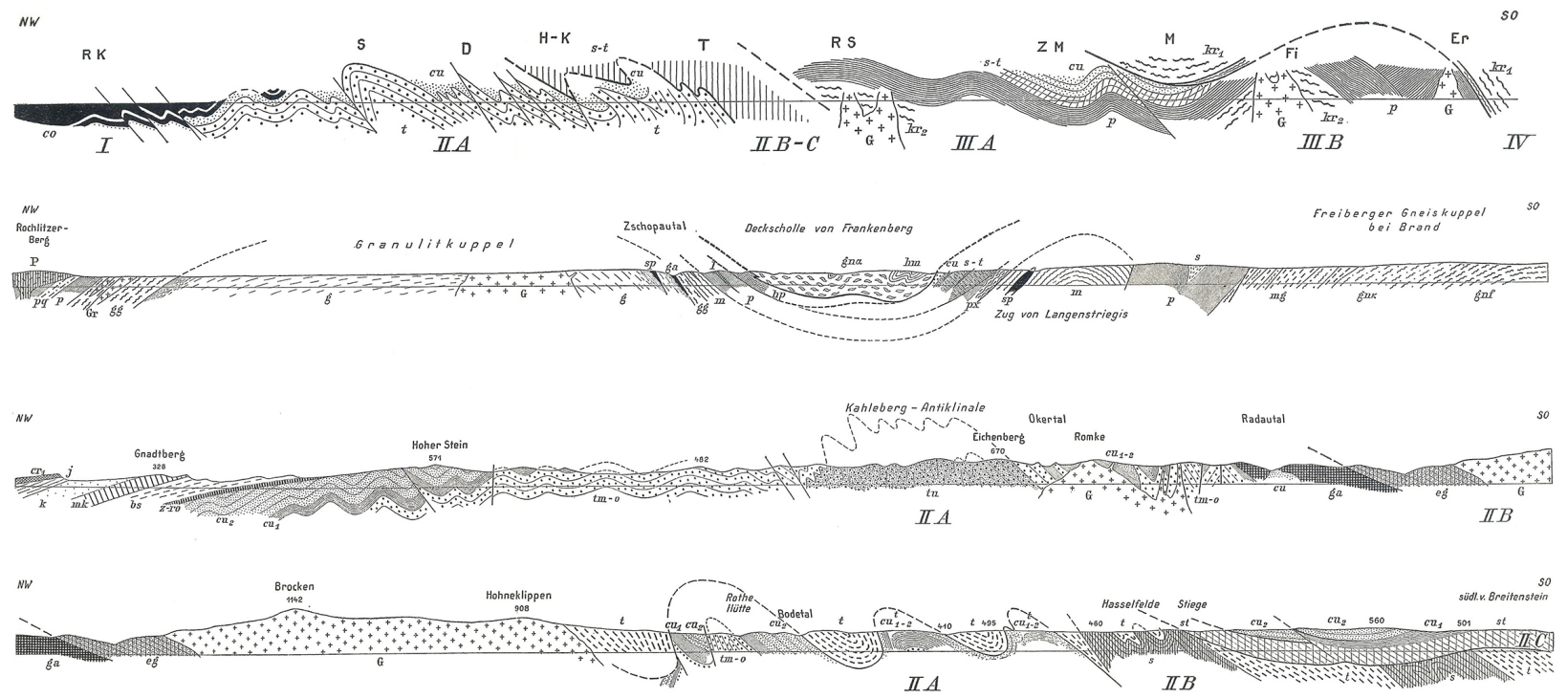

Figure A3. Supporting plate showing cross sections.

Erlåıterung der Tafell II.

Fig. 1. Gesamtprofill durch den Westflitigel des varistischen Bogens.

I. Westeälisehe Zone.

II. Rhenoherzynische Zonen: II A. = Sauerland-Oberharz Zone. II B-C. = westliche Fortsetzung der Unterharz-Decken im östlichen rheinischen Schiefergebirge.

III. Saxothuringische Zonen: III A. = Spessart - Thüringer Wald-Zone.

III B. = Fichtelgebirgse und Erzgebirgszone.

IV. Moldanubische Region mit vorliegender Deckscholle.

Abkürzungen für Gebirgsteile: $\mathrm{RK}=$ Ruhrkohlengürtel, $\mathrm{S}=$ Sauerländer Sattel, $\mathrm{D}=$ Dillmulde, $\mathrm{H}-\mathrm{K}=$ Hörre-Kellerwaldzug, $\mathrm{T}=$ Taunus, $\mathrm{RS}=$ Ruhlaer Sattel, Z.M. = Ziegenrückmulde, Fi = Fichtelgebirge, $M=$ Münchberger Gneisscholle, $\mathrm{Er}=$ Erbendörfer Grundgebirgsgebiet.

Gesteinsgruppen: $\mathrm{kr}_{1}=$ Kristallines Grundgebirge der moldanubischen Region, $\mathrm{kr}_{0}=$ Kristallines Grundgebirge der saxothnringischen Zonen, $\mathrm{p}=$ Phyllite und phyllitische Tonschiefer, $\mathrm{s}=$ Silur, $\mathrm{t}=$ Devon, $\mathrm{cu}=\mathrm{Kulm}$, co $=$ Oberkarbon, $\mathrm{G}=$ Granit.

Fig. 2. Profil vom Grantulitgebirge durch die Frankenberger Deckscholle zum Erzgebirge. Maßstab 1:100c00.

Gesteine des Erzgebirges und Granulitgebirges:

$\mathrm{gnf}=$ Freiberger Grauer Gneis, gnk = feinkörnig-schuppiger Graver Gneis, $\mathrm{mg}=$ Muskowitgneis („Roter Gneis") und schuppiger Granat-Muskowitschiefer,

$\mathrm{ga}=$ Gabbro, $\mathrm{sp}=$ Serpentin, $\mathrm{g}=$ Granulit, $\mathrm{Gr}=$ Lagergranit, $\mathrm{G}=$ Mittweidaer Granit,

$\mathrm{gg}=$ Gneisglimmerschiefer und Cordieritgneis, $\mathrm{m}=$ Glimmerschiefer, $\mathrm{p}=$ Phyllit $\mathrm{pq}=$ Phyllitquarzit, $\mathrm{px}=$ metamorphe Grawacke, $\mathrm{l}=$ eingeklemmte Metakieselschiefer (Silur?).

$\mathrm{s}=$ Silur, $\mathrm{t}=$ Devon, $\mathrm{cu}=\mathrm{Kulm}$

Gesteine der Frankenberger Deckscholle:

gna = Frankenberger Augengneis, $\mathrm{hm}=$ Mnskowit-Hornblendeschiefer, hp $=$ Amphibol-Epidotschiefer ("Prasinitschiefer")

$\mathrm{P}=$ Rotliegendporphyre und Tuffe.

Fig. 3 und 4. Schematisches Harzprofill. Maßstab 1:100000. (Mit Benutzung der geologischen Spezialkarte u. a. m.)

II A. = Oberharzzone: $t_{1}=$ Unterdevon, $t_{2}=$ Mittel- und Oberdevon, $\mathrm{cu}_{1}=\mathrm{Kolm}$ kiesel- und -tonschiefer, $\mathrm{eu}_{2}=$ Kulmgranwacken und Schiefer, $\mathrm{cu}^{t}{ }_{1-2}=$ Tanner Plat tenschiefer, Kieselschiefer und Granwacken (hier ebenfalls als Kulm aufgefaßt). Il B. = Unterharz-Decke: $\mathrm{s}=$ Silur, eg= „Eckergneis ${ }^{\prime \prime}, \mathrm{t}=$ Devon im allgemeinen. II C. = Stieger Decke: st = Stieger Schiefer und Diabase, eu $\mathrm{eu}_{1}=$ Kulmkiesel- und -tonschiefer, $\mathrm{cu}_{2}=$ Kulmgrauwacken und -schiefer.

Intrusivgesteine: ga $=$ Gabbro, $\mathrm{G}=$ Granit.

Postvaristische Decke: z-ro = Zechstein und Oberrotliegendes, bs $=$ Buntsandstein, $\mathrm{mk}=$ Muschelkalk, $\mathrm{k}=$ Keuper, $\mathrm{j}=$ Jura (Lias), $\mathbf{c r}_{1}=$ Untere Kreide.

Figure A4. Explanatory notes to Fig. A3. 


\section{Information about the references}

In the following I list references cited by Kossmat in the original text and references cited by me in the Introductory comments and in footnotes. In the original text some references were cited incorrectly. In the present translation I give the correct references to the best of my knowledge.

Competing interests. The author declares that he has no conflict of interest.

Acknowledgements. I thank Carl-Heinz Friedel for providing high-resolution scans of the supporting plates and Arzu Arslan for carefully reading the manuscript and constructive comments. Finally, I am grateful to Franz Neubauer and Jürgen von Raumer for their thorough reviews of an earlier version of the manuscript that led to an improved final version.

Edited by: K. Schlegel

Reviewed by: J. von Raumer and F. Neubauer

\section{References}

Anonymous: Carte geologique de la Belgique, 1:60000, Blatt 8, Brüssel, 1920.

Bederke, E.: Das Devon in Schlesien und das Alter der Sudetenfaltung, Fortschritte der Geologie und Paläontologie, 7, 1-50, 1924.

Bederke, E.: Bau und Alter des ostsudetischen Gebirges, Neues Jahrbuch für Mineralogie, Geologie und Paläontologie, Abteilung B, Beilagenblatt, 53, 98-116, 1925.

Berg, G.: Die krystallinen Schiefer des östlichen Riesengebirges, Abhandlungen der Königlichen Preußischen Geologischen Landesanstalt, Neue Folge, 68, 188 pp., 1912.

Bode, A.: Über das Herzyn und rheinische Unterdevon des Harzes, besonders der Gegend von Bad Lauterberg, Jahrbuch der Preußischen Geologischen Landesanstalt für 1921, 1921, 42, 187-256, 1923.

Born, A.: Die jungpaläozoischen kontinentalen Geosynklinalen Mitteleuropas, Abhandlungen der Senckenbergischen Naturforschenden Gesellschaft, 37, 507 pp., 1921.

Börngen, M., Jacobs, F. and Schied, G.: Zur Stunde Null unserer Gesellschaft, Mitteilungen der Deutschen Geophysikalischen Gesellschaft, 1-2/2007, 31-34, 2007.

Bukowski, G. v.: Blatt Mährisch-Neustadt und Schönberg, K. K. Geol. Reichsanst., Wien, 1905.

Cloos, H.: Der Gebirgsbau Schlesiens, Gebrüder Borntraeger, Berlin, 107 pp., 1922.

Collet, L. W.: The Structure of the Alps, 2nd Edn., Edward Arnold, London, 304 pp., 1935.

Dahlgrün, F., Erdmannsdörfer, O. H., and Schriel, W.: Sammlung geologischer Führer: Harz, Teil I: Oberharz und Brockengebiet Nr. 29, Teil II: Unterharz und Kyffhäuser Nr. 30, Gebrüder Borntraeger, Berlin, 1925.

Dathe, E. and Zimmermann, E.: Erläuterungen zum Blatt Freiburg der Geologischen Spezialkarte von Preußen, Berlin, 1912.
Denckmann, A.: Der geologische Bau des Kellerwaldes, Abhandlungen der Königlichen Preußischen Geologischen Landesanstalt, Neue Folge, 34, 88 pp., 1901.

Drost, K., Bach, F., Kroner, U., and Lange, J.-M.: Franz Kossmat 1871-1938, 2. Auflage, Miniaturen zur Geologie Sachsens, GeoSzene, 2, Staatliche Naturhistorische Sammlungen Dresden, Dresden, 16 pp., 2005.

Fuchs, A.: Die Stratigraphie des Hunsrückschiefers und der Untercoblenzschichten am Mittelrhein nebst einer Übersicht über die spezielle Gliederung des Devons mittelrheinischer Facies und die Faciesgebiete innerhalb des rheinischen Unterdevons, Abhandlungen der Königlichen Preußischen Geologischen Landesanstalt, Neue Folge, 59, 96-119, 1907.

Geinitz, H. B.: Dyas oder die Zechsteinformation und das Rothliegende, Heft 1: Die animalischen Ueberreste der Dyas, Wilhelm Engelmann, Leipzig, 130 pp., 1861.

Gerth, H.: Gebirgsbau und Fazies im südlichen Teile des Rheinischen Schiefergebirges, Geol. Rundsch., 1, 82-96, 1910.

Jameson, R.: System of Mineralogy, comprehending Oryctognosie, Geonosie, Mineralogical Chemistry, Minerlogical Geography, and Economical Mineralogy, Vol. 1, Archibald Constable and Co., Edinburgh, T. N. Longman and O. Rees, London, 607 pp., 1804.

Kegel, W.: Abriß der Geologie der Lahnmulde. Erläuterung zu einer von Johannes Ahlburg hinterlassenen Übersichtskarte und Profildarstellung der Lahnmulde, Abhandlungen der Preußischen Geologischen Landesanstalt, Neue Folge, 86, 81 pp., 1922.

Kegel, W.: Das Untercarbon und die varistische Faltung im östlichen Lahngebiet, Jahrbuch der Preußischen Geologischen Landesanstalt für 1924, 45, 287-305, 1925.

Kegel, W. and Richter, R.: Zur Stratigraphie der Sattelachse zwischen Lahn- und Dillmulde, Jahrbuch der Preußischen Geologischen Landesanstalt für 1923, 44, 514-516, 1924.

Koch, M.: Überblick über die neuen Ergebnisse der geologischen Forschung im Unterharz, Zeitschrift der Deutschen Geologischen Gesellschaft, 7-18, 1897.

Kossmat, F.: Übersicht der Geologie von Sachsen, 1. Auflage, Leipzig, 63 pp., 1916 a.

Kossmat, F.: Über die Tektonik des Gneisgebietes im westlichen Erzgebirge, Centralblatt für Mineralogie, Geologie und Paläontologie, 135-144 and 158-165, 1916 b.

Kossmat, F.: Die mediterranen Kettengebirge in ihrer Beziehung zum Gleichgewichtszustand der Erdrinde, Abhandlungen der Sächsischen Akademie der Wissenschaften, MathematischPhysikalische Klasse, 38, 1-61, 1921.

Kossmat, F.: Geologie der zentralen Balkanhalbinsel: Mit einer Übersicht des dinarischen Gebirgsbaus, in: Die Kriegsschauplätze 1914-1918 geologisch dargestellt, Heft 12, edited by: Wilser, J., Gebrüder Borntraeger, Berlin, 198 pp., 1924.

Kossmat, F.: Übersicht der Geologie von Sachsen, 2. Auflage, Leipzig, 129 pp., 1925a.

Kossmat, F.: Erscheinungen und Probleme des Überschiebungsbaus im varistischen Gebirge Sachsens und der Sudetenländer, Centralblatt für Mineralogie, Geologie und Paläontologie, Abteilung B, 198 pp., 11, 354 pp., 1925b.

Kossmat, F.: Ein Problem der Harztektonik: Der Überschiebungsbau des Unterharzes, Centralblatt für Mineralogie, Geologie und Paläontologie, Abteilung B, 33-49, 1927a. 
Kossmat, F.: Gliederung des varistischen Gebirgsbaues, Abhandlungen des Sächsischen Geologischen Landesamts, 1, 1-39, $1927 b$.

Lauterbach, R.: Franz Kossmat - Gedanken zum 100. Geburtstag eines großen Geologen, Geologie, 21, 1015-1021, 1972.

Leppla, A.: Zur Stratigraphie und Tektonik der südlichen Rheinprovinz, Jahrbuch der Preußischen Geologischen Landesanstalt für 1924, 45, 1-88, 1925.

Ludwig, C. F.: Handbuch der Mineralogie nach A. G. Werner, Vol. 2, Siegfried Lebrecht Crusius, Leipzig, 226 pp., 1804.

Marcou, M. J.: Dyas et Trias ou le Nouveau Grès Rouge en Europe dans l'Amerique du Nord et dans l'Inde, 1-63, Archiv des Sciences de la Bibliothèque Universelle, Ramboz et Schuchardt, Genève, 1859.

Michels, F.: Zur Tektonik des südlichen Taunus, Sitzungsberichte der Preußischen Geologischen Landesanstalt, 1, 73-77, 1926.

Moesta, F. and Beyrich, F.: Blatt Allendorf der Geologischen Spezialkarte von Preußen, Berlin, 1886.

Murchison, Sir R. I.: On the inapplicability of the new term "Dyas" to the "Permian" group of rocks, as proposed by Dr. Geinitz, Philos. Mag. S., 4, 65-70, 1862.

Paeckelmann, W.: Geologisch-tektonische Übersichtskarte des Rheinischen Schiefergebirges, 1:200000, Preußische Geologische Landesanstalt, Berlin, 1926.

Paeckelmann, W.: Bemerkungen über die geologischen Verhältnisse der Umgebung von Brilon in Westfalen, Jahrbuch der Preußischen Geologischen Landesanstalt für 1926, 46, 211-230, 1927.

Philippsborn, H. v.: Über mylonitische Granitgneise in der nördlichen Randzone des sächsischen Granulitgebirges, Berichte der Sächsischen Akademie der Wissenschaft, MathematischPhysikalische Klasse, 75, 38-57, 1923.

Pietzsch, K.: Das Elbtalschiefergebirge südwestlich von Pirna, Zeitschrift der Deutschen Geologischen Gesellschaft, 69, 177286, 1917.

Raumer, K. v.: Das Schiefergebirge des nordwestlichen Deutschlands, der Niederlande und des nordöstlichen Frankreichs: Ein geognostischer Versuch, in: Geognostische Versuche, edited by: von Engelhardt, M. and Raumer, K. v., Realschulbuchhandlung, Berlin, 133 pp., 1815.

Scheumann, K. H.: Prävariskische Glieder der sächsischfichtelgebirgischen kristallinen Schiefer. I. Die magmatisch orogenetische Stellung der Frankenberger Gneisgesteine, Abhandlungen der Sächsischen Akademie der Wissenschaften, Mathematisch-Physikalische Klasse, 39, 61 pp., 1924.

Scheumann, K. H.: Die gesteins- und mineralfazielle Stellung der Metakieselschiefergruppe der südlichen Randzone des sächsischen Granulitgebirges, Abhandlungen der Sächsischen Akademie der Wissenschaften, Mathematisch-Physikalische Klasse, 39, 48 pp., 1925.

Schindewolf, O. H.: Einige Bemerkungen über das SphaerocodienKonglomerat von Alt-Liebichau bei Freiburg in Niederschlesien, Zeitschrift der Deutschen Geologischen Gesellschaft, 77, 84-96, 1925.

Schriel, W.: Transgressionen und Gebirgsbildungen im älteren Paläozoikum des südlichen Mittelharzes, Jahrbuch der Preußischen Geologischen Landesanstalt für 1924, 45, 200-248, 1925.
Seibold, I. and Seibold, E.: Neues aus dem Geologen-Archiv (1990). Mit Erinnerungen an Franz Kossmat, Geol. Rundsch., 80, 801-804, 1991.

Seidl, J.: Von der Geognosie zur Geologie. Eduard Sueß (18311914) und die Entwicklung der Erdwissenschaften an den österreichischen Universitäten in der zweiten Hälfte des 19. Jahrhunderts, Jahrbuch der Geologischen Bundesanstalt, 149, 375-390, 2009.

Şengör, A. M. C.: Eduard Suess and global tectonics: an illustrated "Short Guide", Austrian Journal of Earth Sciences, 107, 6-82, 2014.

Stille, H.: Grundfragen der vergleichenden Tektonik, Gebrüder Borntraeger, Berlin, 443 pp., 1925.

Suess, E.: Das Antlitz der Erde, Vol. II, F. Tempsky, Prag-Wien and G. Freytag, Leipzig, 703 pp., 1888.

Suess, E.: Das Antlitz der Erde, Vol. III/2 (Dritter Band. Zweite Hälfte. Schluss des Gesamtwerkes), F. Tempsky, Wien, and G. Freytag, Leipzig, 789 pp., 1909.

Suess, F. E.: Die Moravischen Fenster und ihre Beziehungen zum Grundgebirge des hohen Gesenkes, Denkschrift der Kaiserlichen Akademie der Wissenschaften in Wien, MathematischNaturwissenschaftliche Klasse, 88, 541-631, 1912a.

Suess, F. E.: Vorläufige Mitteilungen über die Münchberger Deckscholle, Sitzungsberichte der Kaiserlichen Akademie der Wissenschaften in Wien, Mathematisch-Naturwissenschaftliche Klasse, Abteilung, 2a 121, 1-253, 1912 b.

Suess, F. E.: Intrusionstektonik und Wandertektonik im variszischen Grundgebirge, Gebrüder Borntraeger, Berlin, 268 pp., 1926.

Tietze, E.: Die geognostischen Verhältnisse der Gegend von Olmütz, Jahrbuch der Kaiserlich-Königlichen Geologischen Reichsanstalt, 43, 399-566, 1893.

Tollmann, A.: Klippe, in: Structural Geology and Tectonics, edited by: Seyfert, C., Encyclopedia of Earth Sciences, 377-381, 1987.

Walcott, C. D.: Stratigraphic position of the Olenellus fauna in North America and Europe, Am. J. Sci., 37, 374-392, 1889.

Welter, O. A.: Über die Deutung des Iberges bei Grund im Harz, Sitzungsberichte der niederrheinischen Gesellschaft für Naturund Heilkunde Bonn, 1-7, 1910.

Werner, A. G.: Kurze Klassifikation und Beschreibung der verschiedenen Gebirgsarten, Waltherische Hofbuchhandlung, Dresden, 28 pp., 1787.

Wilser, J. L.: Die Steinkohlen in der Schwarzmeer-Umrandung, insbesondere bei Heraklea-Zonguldag (Nordanatolien), Geol Rundsch., 18, 1-37, 1927.

Winkler-Hermaden, A.: Franz Kossmat, Jahrbuch der Geologischen Bundesanstalt, 88, 395-401, 1938.

Wurm, A.: Geologie von Bayern, Gebrüder Borntraeger, Berlin, 373 pp., 1925.

Wurm, A.: Über den Bauplan des variskischen Gebirges am Westrand der Böhmischen Masse, Geologische Rundschau, 17, 241 257, 1926.

Zimmermann, E.: Erläuterungen zu Blatt Schweidnitz der preußischen geologischen Spezialkarte, Berlin, 1924. 